\title{
Toll-like receptor 4 signaling in liver injury and hepatic fibrogenesis
}

\author{
Jinsheng Guo ${ }^{1}$, Scott L Friedman ${ }^{2 *}$
}

\begin{abstract}
Toll-like receptors (TLRs) are a family of transmembrane pattern recognition receptors (PRR) that play a key role in innate and adaptive immunity by recognizing structural components unique to bacteria, fungi and viruses. TLR4 is the most studied of the TLRs, and its primary exogenous ligand is lipopolysaccharide, a component of Gramnegative bacterial walls. In the absence of exogenous microbes, endogenous ligands including damage-associated molecular pattern molecules from damaged matrix and injured cells can also activate TLR4 signaling. In humans, single nucleotide polymorphisms of the TLR4 gene have an effect on its signal transduction and on associated risks of specific diseases, including cirrhosis. In liver, TLR4 is expressed by all parenchymal and non-parenchymal cell types, and contributes to tissue damage caused by a variety of etiologies. Intact TLR4 signaling was identified in hepatic stellate cells (HSCs), the major fibrogenic cell type in injured liver, and mediates key responses including an inflammatory phenotype, fibrogenesis and anti-apoptotic properties. Further clarification of the function and endogenous ligands of TLR4 signaling in HSCs and other liver cells could uncover novel mechanisms of fibrogenesis and facilitate the development of therapeutic strategies.
\end{abstract}

\section{Introduction}

Toll-like receptors (TLRs) are evolutionarily conserved trans-membrane proteins originally identified in mammals on the basis of their homology with Toll, a Drosophila receptor that contributes to development in the embryo, and in the production of antimicrobial peptides against microorganism invasion in the adult fly $[1,2]$.

TLRs are a family of pattern-recognition receptors that recognize pathogen-derived molecules termed pathogen-associated molecular patterns (PAMPs), which are structural components unique to bacteria, fungi and viruses. These ligands bind to TLRs, leading to signaling and activation of innate and adaptive inflammatory responses.

Ten TLRs have been identified in humans [3], which have individual or shared substrates for activation, and recognize microbes either on the cell surface or on lysosome/endosome membranes (Table 1). Toll-like receptor (TLR) 4 was the first to be discovered, and is the most important Toll homolog; it responds primarily to its main ligand, lipopolysaccharide (LPS).

\footnotetext{
* Correspondence: scott.friedman@mssm.edu

${ }^{2}$ Division of Liver Diseases, Mount Sinai Hospital, Mount Sinai School of Medicine, New York, NY, USA

Full list of author information is available at the end of the article
}

Recent studies indicate that TLR4 signaling can also be activated by some endogenous ligands from cellular compartments, which are released and/or increased during tissue injury and matrix degradation. These ligands are collectively referred to as damage-associated molecular patterns (DAMPs).

There is rapidly increasing knowledge both about TLR4 signaling in cells and about the association of single nucleotide polymorphisms (SNPs) of the TLR4 gene with the risks and mechanisms of human diseases. In liver, both parenchymal and non-parenchymal cell types express TLR4, which is actively involved in the response to injury from a variety of etiologies, including viral hepatitis, alcoholic and non-alcoholic liver diseases, autoimmune liver diseases and drug-induced liver diseases. TLR4 signaling is present in activated hepatic stellate cells (HSCs), the major fibrogenic cell type in injured liver, and mediates the inflammatory phenotype and survival of the cell. Recent studies have uncovered an important role for TLR4 signaling in liver fibrogenesis and the association of TLR4 polymorphisms with fibrosis risk.

In this review, we introduce TLR signal transduction and the functional role of TLR4 signaling in liver injury 
Table 1 Toll-like receptor (TLR) family and ligands

\begin{tabular}{lll}
\hline TLR & Ligands & Cellular location \\
\hline TLR1 & Triacylated bacterial lipopeptides & Cell membrane \\
\hline TLR2 & Triacylated bacterial lipopeptides & Cell membrane \\
\hline TLR3 & Double-stranded RNA produced by most viruses during replication & Endosomal \\
& & compartment \\
\hline TLR4 & $\begin{array}{l}\text { Lipopolysaccharide, low-molecular weight hyaluronic acid, heparin sulfate, saturated fatty acid, fibrinogen, fibronectin, } \\
\text { heat shock proteins } 60 \text { and 70, high mobility group box-1, degraded matrix }\end{array}$ & Cell membrane \\
\hline TLR5 & Bacterial flagellin & Cell membrane \\
\hline TLR6 & TLR1 and 6 combine with TLR2 to distinguish the subtle differences between triacyl and diacyl lipopeptides & Cell membrane \\
\hline TLR7 & ssRNA viruses, influenza virus & Endosomal \\
& & compartment \\
\hline TLR8 & ssRNA & Endosomal \\
& & compartment \\
\hline TLR9 & Unmethylated CpG DNA found in bacteria, DNA virus & Endosomal \\
& & compartment \\
\hline TLR10 & unknown & Cell membrane \\
\hline
\end{tabular}

${ }^{1}$ ssRNA = single-stranded RNA.

and fibrogenesis, pointing towards the potential to develop specific therapeutics.

\section{Components of the TLR4 signaling pathway}

TLRs mediate a tightly integrated signal transduction cascade linking a series of protein-protein interactions with their ligands, receptors, co-receptors and adaptor proteins to convey downstream signals that control transcription [4] (Figure 1). Genes regulated by TLRs include cytokines and proteins controlling innate and adaptive immunity, cell survival and apoptosis, and fibrogenesis.

\section{TLR4 and co-receptors}

Human TLRs are type I transmembrane glycoproteins that are structurally characterized by the presence of a leucine-rich repeat (LRR) domain in their extracellular structure, and a conserved Toll/interleukin (IL)-1 receptor (TIR) homology domain in their intracellular domains.

The extracellular domain is unique to each individual TLR, as it confers specificity for ligand recognition. For example, for the initiation of LPS to activate intracellular TLR4 signaling, the ligand first interacts with circulating LPS-binding protein (LBP) along with three LRR domain-containing proteins, TLR4 and the two coreceptors CD14 and myeloid differentiation protein (MD)2, together comprising the LPS receptor complex [5]. CD14 is a $55 \mathrm{kDa}$ glycophosphatidylinositol-linked protein expressed on the surface of LPS-responsive cells such as macrophages and monocytes. Alone, CD14 cannot transduce a signal intracellularly because it lacks a transmembrane domain. Instead, it transfers LPS to a hydrophobic pocket within the MD2 glycoprotein, resulting in TLR4-dependent activation of cells. MD2 is a glycoprotein of approximately 17 to $25 \mathrm{kDa}$, and is present with TLR4 at the surface of various cell types, principally those of the myeloid and endothelial lineages. Despite the absence of a transmembrane domain, MD2 can attach to the cell surface via its interaction with TLR4 through specific epitopes. Human MD2 is an accessory molecule expressed on the cell surface that is not only required for cell-surface expression of TLR4, but also appears to be essential for the activation of the TLR4 signaling cascade. Activation of TLR4 by LPS absolutely requires the presence of the co-receptor MD2 for signaling, whereas some TLR4mediated signals may still be generated in the absence of CD14.

Both CD14 and MD2 are soluble acute phase proteins [6]. They may act as a sink for LPS, and participate in opsonization and internalization of Gram-negative bacteria by human phagocytes.

\section{Adaptors}

Upon LPS recognition, TLR4 undergoes oligomerization and recruits its downstream adaptors through interactions with the TIR domains. Four adaptor proteins (myeloid differentiation factor (MyD)88, MyD88-adaptor-like/TIR domain-containing adaptor protein (MAL/ TIRAP) [7], TIR domain-containing adaptor inducing interferon- $\beta$ (TRIF) and TRIF-related adaptor molecule (TRAM) $[8,9]$ ) transduce signals from all of the TIR domains and engage downstream signaling proteins. The function of a fifth adaptor, SARM (sterile alpha and HEAT/Armadillo motif protein), has yet to be defined. Different TLRs use different combinations of adaptor proteins to determine downstream signaling; TLR4 is 


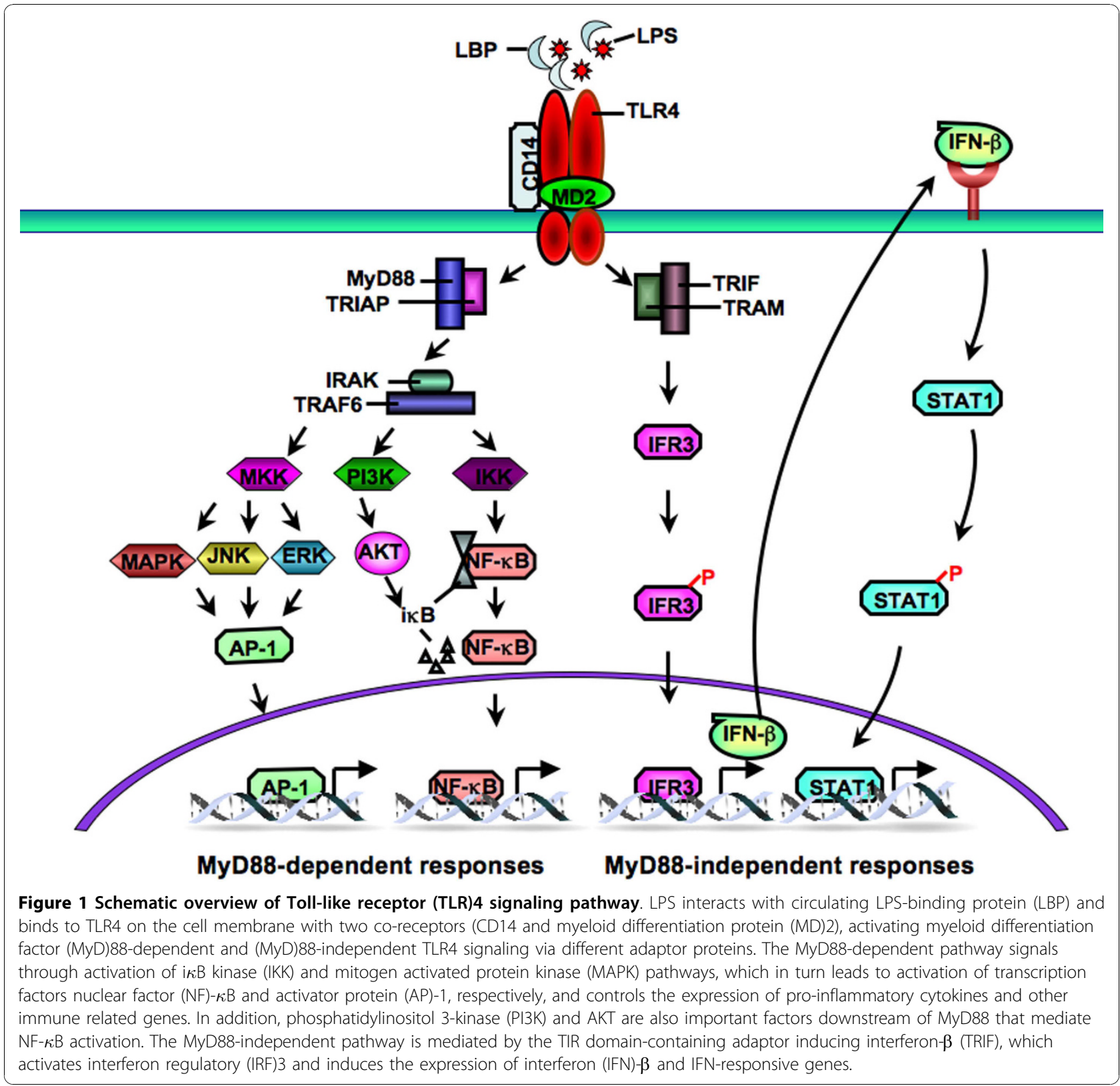

the only known TLR that uses all these adaptor proteins.

TLR4 signaling has been divided into MyD88-dependent and MyD88-independent, TRIF-dependent pathways. The MyD88-dependent pathway signals through IL-1 receptor-associated kinase (IRAK)-1, IRAK-4, tumor necrosis factor (TNF) receptor-associated factor (TRAF) 6 , and transforming growth factor- $\beta$-activated kinase (TAK)1, which activates downstream $\mathrm{i} \kappa \mathrm{B}$ kinase (IKK) and mitogen-activated protein kinase (MAPK) pathways [10]. These events in turn lead to activation of the transcription factors nuclear factor $(\mathrm{NF})-\kappa \mathrm{B}$ and activator protein (AP)-1, respectively, and control the expression of pro-inflammatory cytokines and other immune related genes. In addition, phosphatidylinositol 3-kinase (PI3K) and AKT are also important factors downstream of MyD88 that mediate NF- $\kappa$ B activation $[11,12]$. The MyD88-independent pathway is mediated by TRIF, which activates interferon regulatory factor (IRF) 3 and induces the expression of interferon (IFN) $-\beta$ and IFN-responsive genes [13]. The MyD88-independent pathway also mediates the late-phase activation of NF- $\kappa \mathrm{B}$ and MAPK. The activation of two signaling pathways downstream of TLR4 is cell-specific and dependent 
on the dose of the ligands [14]. Interestingly, LPS is unable to activate the MyD88-independent pathway in terminally mature neutrophils [15].

\section{Transcription factors}

At least three major transcriptional complexes are involved in TLR4 signaling: NF- $\kappa \mathrm{B}, \mathrm{AP}-1$ and IFN regulatory factors (IRFs). These nuclear factors have important activities in HSCs (see below) and other resident liver cell populations. However, a comprehensive understanding of which transcriptional complexes are downstream of TLR4 in each cell type is lacking, and warrants further investigation.

\section{NF- $\kappa$ B}

$\mathrm{NF}-\kappa \mathrm{B}$ is a pleiotropic protein complex that is activated from a sequestered, cytoplasmic form normally retained in the cytoplasm by binding to $\mathrm{i} \kappa \mathrm{B}$ (the NF- $\kappa \mathrm{B}$ inhibitor protein) via pro-inflammatory extracellular signals and cellular stress. However, after $\mathrm{i} \kappa \mathrm{B}$ degradation, initiated by a complex signaling cascade initiated at the cell surface (for example, TLR4 signaling), the active form of $\mathrm{NF}-\kappa \mathrm{B}$ translocates into the nucleus, where it activates transcription.

NF- $\kappa \mathrm{B}$ regulates hundreds of cellular genes including cytokines, chemokines, adhesion molecules that participate in the regulation of innate and adaptive immunity, and proteins that regulate cell-cycle progression (for example, cyclin D1) and cell survival (for example, Bcl$2, \mathrm{Bcl}-\mathrm{xL}$ and Bfl-1). Both pro- and anti-apoptotic gene products are regulated by NF- $\kappa \mathrm{B}$, depending on the cell type and the stimulus [16].

NF- $\kappa \mathrm{B}$ activity can be perturbed in a variety of nonparenchymal and parenchymal liver cells during hepatic inflammation, fibrosis and the development of hepatocellular carcinoma, and regulates the interplay between immune, fibrogenic and oncogenic mediators [17]. Hepatic NF- $\kappa \mathrm{B}$ is implicated in homeostatic processes such as: clearance of microbial pathogens, protection of hepatocytes from TNF- $\alpha$-induced cell death, and compensatory proliferation of hepatocytes in response to loss of hepatic mass after liver injury [18]. NF- $\kappa \mathrm{B}$ signaling has vast complexity, and the NF- $\kappa \mathrm{B}$ activities are context-dependently regulated by subunit interactions, post-translational modification and recruitment of coregulators.

Activated HSCs have persistently activated NF- $\kappa \mathrm{B}$, with a reduction in $\mathrm{i} \kappa \mathrm{B}$ expression. As a result, many $\mathrm{NF}-\kappa \mathrm{B}$ responsive genes are constitutively expressed in activated, but not in quiescent HSCs. Inhibiting NF- $\kappa \mathrm{B}$ activation does not alter the activated cellular morphology of HSCs, or the expression of either $\alpha$-smooth muscle actin ( $\alpha$-SMA) or collagen; however, NF- $\kappa$ B plays an important role in the anti-apoptotic property of activated HSCs and hepatic myofibroblasts [19]. It also mediates the regulation of the TGF- $\beta 1$ pseudoreceptor BAMBI (bone morphogenic protein and active membrane bound inhibitor) in HSCs by TLR4-MyD88 activation, thus sensitizing the cell to TGF- $\beta 1$ signaling [20].

\section{AP-1}

The transcription factor AP-1 is composed of either homodimers or heterodimers of members of the Jun (cJun, v-Jun, Jun-B and Jun-D) and Fos (c-Fos, Fos-B, Fra1 and Fra-2) families, and regulates cell proliferation, differentiation and survival. The regulation of AP-1 activity is complex, which can be achieved by modulating jun and fos gene transcription and mRNA turnover; Jun and Fos protein turnover; post-translational modifications of Jun and Fos proteins that modulate their transactivation potential; or interactions of AP-1 with other transcription factors that can either synergize or interfere with its activity. Various stimuli, such as physiological agents (growth factors, mitogens, polypeptide hormones, cell-matrix interactions and inflammatory cytokines), bacterial and viral infections, pharmacological compounds (phorbol esters), cellular stress (ultraviolet or ionizing radiation, hyperosmotic and heavy-metal stress), can induce AP-1 activity. These stimuli activate MAPK cascades by phosphorylating distinct substrates, mostly for p38, Jun amino-terminal kinase (JNK) and extracellular signal-regulated kinase (ERK), which enhance AP-1 activity.

In activated HSCs, AP-1 represents another family of transcription factors that has increased and persistent activity. AP-1 is a downstream effector of MAPK signaling that contributes to TGF- $\beta 1$ and platelet-derived growth factor-induced HSC fibrogenesis and proliferation, respectively. In addition, AP-1 regulates tissue inhibitor of metalloproteinase (TIMP), matrix metalloproteinase (MMP) and other genes involved in matrix remodeling [21-23]. Jun D is the most important AP-1 factor in activated HSCs, as it is required for both TIMP-1 and IL-6 gene expression [22].

AP-1 can combine with several transcription factors to form complexes that synergistically mediate the transcription of fibrogenic genes. Examples of these crucial combinations include the cooperation of Smad3/4 complex with AP-1 in mediating TGF- $\beta 1$-induced $\alpha 2(\mathrm{I})$ collagen transcription [24], assembly of the Jun D and RunX factors at the TIMP-1 promoter to stimulate gene transcription [25], and NF- $\kappa \mathrm{B}$ - and AP-1-mediated, IL$1 \beta$-stimulated TGF- $\beta 1$ transcription [26].

\section{IRFs and STAT1}

A family of IRFs regulate the transcription of IFN genes and IFN-stimulated genes. The MyD88-independent TRIF-dependent TLR4 pathway activates IRF3, and 
induces the expression of IFN- $\beta$ and IFN-responsive genes [13,27], whereas IRF1 is activated via MyD88dependent pathways. IRF1 rapidly translocates to the nucleus, and cooperates with IRF3 in response to LPS for the initial induction of target genes, including IL27p28 [28].

Activation of signal transducers and activators of transcription 1(STAT1) by TLR4 signaling can occur directly via a protein kinase $(\mathrm{PK}) \mathrm{C}-\delta$ related mechanism [29] or indirectly by the induction of IFN- $\beta$ via MyD88independent IRF3 activation [13]. In the indirect mechanism, STAT1 is tyrosine-phosphorylated and dimerized after antocrine/paracrine interactions within IFN- $\beta$ and IFN $\alpha / \beta$ receptors on the surface of cells, which result in the crossactivation of the receptor-associated Janus protein tyrosine kinases (JAKs). The activated STAT1 in turn regulates the expression of several STAT1-dependent genes [30], including genes involved in growth control and that mediate the responses of IFN types (for example, IFN- $\gamma$ ) to viral infections and other pathological agents.

\section{Downstream factors}

The downstream factors regulated by TLR4 signaling include:

1. Effectors of the innate immune response: proinflammatory cytokines (TNF- $\alpha$, IL-1, IL-6), chemotactic cytokines (monocyte chemotactic protein (MCP)-1, macrophage migration inhibitory factor (MIF)), proinflammatory proteins (inducible nitric oxide synthase (iNOS)), reactive oxygen species (ROS); adhesion molecules (intercellular adhesion molecule (ICAM)-1, vascular cell adhesion molecule (VCAM)-1) and other effectors of the innate immune response (for example, IFN- $\gamma$ ). Products of the inflammatory cascade such as IL-1, TNF- $\alpha$ and cyclooxygenase (COX)-2 can further amplify the inflammatory response.

2. Proteins that regulate cell-cycle progression (for example, cyclin D1) and the apoptotic threshold (for example, Bcl-2, Bcl-xL and Bfl-1).

3. The TGF- $\beta 1$ pseudoreceptor BAMBI [20], which is downregulated by a TLR4-MyD88-NF- $\kappa \mathrm{B}$ dependent pathway, thereby sensitizing HSCs to TGF- $\beta 1$ signaling. Rregulation of BAMBI by TLR4 signaling provides a link between pro-inflammatory and profibrogenic signals [31].

\section{Negative regulation of TLR4 signaling}

TLR4 signaling can be controlled at multiple levels by many regulators [4]. These (mostly inhibitory) pathways are necessary to protect the host from inflammationinduced damage. The key regulators include:

1. Radioprotective (RP)105, ST2L (also known as IL1R1) and single immunoglobulin IL-1R-related molecule (SIGIRR), which are expressed on the cell surface, interact with TLR4, MD2, MyD88 and TIRAP, and inhibit the initiation of TLR4 signaling.

2. TRIAD3A (Triad domain-containing protein 3, variant A) and suppressor of cytokine signaling (SOCS)1, which are two E3 ubiquitin protein ligases involved in LPS/TLR4 signaling. TRIAD3A can interact with certain TIR domain-containing proteins such as TIRAP and TRIF, and promote their degradation. SOCS-1 was identified as a cytokine regulator that inhibits JAK-STAT signaling. SOCS-1 can induce the ubiquitination of TIRAP, leading to its subsequent degradation [32].

3. Other intracellular negative regulatory proteins act further downstream in the signaling pathway, and include IRAK-M (IRAK family member but lacks kinase activity), IRAK-2c and MyD88s (splicing variants of IRAK and MyD88), TRAF1 and TRAF4 (TRAF family members that interact with TRIF activity), A20 (a deubiquitinating enzyme that can remove ubiquitin moieties from TRAF6) [33], and syntenin [34].

4. Activating transcription factor (ATF) 3, a member of the cAMP response element binding (CREB)/ATF family of transcription factors that negatively regulates TLR4stimulated inflammatory responses by altering chromatin structure and interacting with regulatory regions of targeted genes (for example, NF- $\kappa \mathrm{B}$ and AP-1 promoter binding sites) $[35,36]$.

5. Let-7i, a cellular micro (mi)RNA, regulates TLR4 expression via post-transcriptional suppression [37]. The miRNAs are a newly identified class of endogenous small regulatory RNAs in the cytoplasm that associate with messenger RNAs based on complementarity between the miRNAs and the target mRNAs $[38,39]$. This binding causes either mRNA degradation or translational suppression, resulting in gene suppression at a post-transcriptional level. Human biliary epithelial cells (cholangiocytes) express let-7 family members, which are decreased in response to Cryptosporidium parvum infection and LPS, and are associated with upregulation of TLR4 and improved epithelial defense responses [37].

\section{Ligands}

\section{Exogenous ligands}

The exogenous ligands of TLRs that are related to pathogen and host defense are referred to as PAMPs. LPS is the well-characterized PAMP for TLR4, and is the principal glycolipid component of the outer membrane of Gram-negative bacteria. TLR4 plays an important role in mediating LPS-induced inflammatory signaling and infectious diseases. TLR4 also recognizes proteins from respiratory syncytial virus, vesicular stomatitis virus and mouse mammary tumor virus [40-42].

\section{Endogenous ligands}

Besides its natural exogenous substrate LPS, there are endogenous substrates for TLR4 that also bind and 
activate TLR4 [43], including low molecular weight hyaluronic acid [44,45], free fatty acids (FFAs) [46], fibrinogen [47], fibronectin [48], heat shock proteins (HSPs) 60 and $70[49,50]$ and high mobility group box (HMGB) 1 [51]. In vivo, damage signals and intact extracellular matrix (ECM) degradation activate TLR4 [52].

Most of these endogenous ligands are released and/or increased during tissue injury and matrix degradation, and are now referred to as DAMPs. Release of DAMPs into the extracellular space is achieved by a number of mechanisms, including: leakage from necrotic cells; increased synthesis and post-translational modification in response to inflammation; and degradation of inactive precursors into TLR-mimetic degradation products in inflammatory environments. DAMPs mediate non-sterile inflammation by activating TLR4 signaling [53].

Most of the endogenous TLR4 ligands have been studied in macrophages, monocytes and neutrophils, and in cells from $\mathrm{C} 3 \mathrm{H} / \mathrm{HeJ}$ mice, which lack a functional TLR4 receptor because of a missense point mutation that results in the substitution of histidine for proline within the cytoplasmic portion of TLR4. The direct effect of these DAMPs on activated HSCs, which have intact TLR4 signaling $[10,20,54]$, is yet to be delineated, and has potential importance for further clarifying the mechanisms of fibrogenesis.

HMGB1 HMGB1 is a highly conserved nuclear non-histone DNA-binding protein that functions as a structural co-factor that is crucial for proper transcriptional regulation in somatic cells. It induces bends in the helical DNA structure to facilitate multiple physical interactions of DNA with transcription factors, recombinases and steroid hormone receptors, and thus allows transcription and other nuclear events to take place. In addition to this transcription factor-like function, HMGB1 also has cytokine-like effects by promoting tumor metastasis and inflammation, which require its presence in the extracellular space. In vitro studies indicate that HMGB1 stimulates HSCs proliferation and expression of $\alpha$-SMA [55].

Release of HMGB1 into the extracellular space is mediated by two mechanisms:

1. Acetylation of many of the lysine residues of HMGB1 that lie in proximity to its two nuclear-localization signals, thus reducing interaction with the nuclear importer protein complex and preventing nuclear reentry while promoting secretion of HMGB1. This active HMGB1 secretion seems to occur predominantly in inflammatory cells.

2. Passive diffusion of HMGB1 from cells that undergo necrosis. The release of HMGB1 does not occur from apoptotic cells, presumably because HMGB1 is tightly bound to cruciform DNA and to hypoacetylated proteins within the nucleus of the apoptotic cell, whereas it is only loosely bound to DNA in necrotic cells. HMGB1 has been suggested as a signature DAMP that signals the presence of necrosis, and subsequently triggers inflammation.

HMGB1 is a late mediator of lethality, and contributes to the increased levels of circulating and tissue cytokines that are present hours to days after the initial exposure to LPS [56]. Transfection with dominant-negative constructs of TLR2 and TLR4 into macrophage cell lines demonstrates that both of these TLRs are involved in HMGB1-induced activation of NF- $\kappa \mathrm{B}$ [51].

Mrp8 and Mrp14 The migration inhibitory factor(MIF)-related protein (MRP)-8, encoded by Mrp8, also known as S100A8) and MRP14 (encoded by Mrp14, also known as S100A9) are the most abundant cytoplasmic proteins of neutrophils and monocytes. They belong to the calcium-binding S100 protein family and form a heterodimeric complex in a $\mathrm{Ca}^{2+}$-dependent manner. Both proteins are specifically released during the activation of phagocytes, and have an important role in the pathogenesis of sepsis.

Expression and release of MRP8-MRP14 complexes by phagocytes correlates with disease activity in many inflammatory disorders. The complexes induce an inflammatory and prothrombotic response in endothelial cells in vitro, and promote leukocyte-endothelial cell interactions [57,58]. The Mrp8-Mrp14 complexes amplify the endotoxin-triggered inflammatory responses of phagocytes, enhance the expression of TNF- $\alpha$, and promote lethality during septic shock [59]. Mrp14-deficient mice have decreased systemic inflammation, lower cytokine plasma concentrations, and less severe liver damage during abdominal sepsis [60]. Using phagocytes obtained from mice expressing a non-functional TLR4 mutant protein, and HEK293 cells (human embryonic kidney cells) replaced with exogenous expression of TLR4, MRP8 was demonstrated to interact specifically with the TLR-MD2 complex, thus representing an endogenous ligand of TLR4 [59].

Fibrinogen Fibrinogen is a $340 \mathrm{kDa}$ multimeric glycoprotein that has crucial functions in vascular hemostasis. It is normally confined to the vasculature, but at sites of inflammation, increased vascular permeability allows plasma extravasation. The concentration of circulating fibrinogen and the deposition of local fibrinogen increases significantly during inflammatory responses. LPS and fibrinogen stimulate the expression of similar cytokines (for example, IL-6) and chemokines (for example, $\mathrm{MCP}-1$ ), and activate the transcriptional factors NF- $\kappa \mathrm{B}$ and AP-1 in macrophages, fibroblasts and endothelial cells $[47,61]$. Macrophages from $\mathrm{C} 3 \mathrm{H} / \mathrm{HeJ}$ mice that express mutant TLR4 fail to respond to fibrinogen, indicating that innate responses to fibrinogen and bacterial endotoxin may converge at the evolutionarily conserved Toll-like recognition molecules [47]. 
Fibronectin Cellular fibronectin, which contains alternatively spliced exons encoding type III repeat extra domain (ED)A and EDB, are produced in response to tissue injury. Fragments of fibronectin or specific fibronectin domains are believed to play important roles in physiological and pathological processes, including tissue remodeling in response to inflammation. The responses of cells exposed to recombinant EDA or EDA-containing fibronectin are similar to those observed when cells are treated with bacterial LPS, including the induction of genes encoding proinflammatory cytokines and MMPs. Recombinant EDA, but not other recombinant fibronectin domains, activates human TLR4 expressed in a cell type (HEK293) that normally lacks this TLR. EDA stimulation of TLR4 is dependent upon co-expression of MD2, a TLR4 accessory protein [48].

Hyaluronan Hyaluronan is a negatively charged, high molecular weight glycosaminoglycan, which is ubiquitously distributed in the ECM and is a component of the basement membrane. At sites of inflammation and tissue destruction, high molecular weight hyaluronan can be broken down to lower molecular weight hyaluronan fragments via oxygen radicals and enzymatic degradation. In contrast to high molecular weight hyaluronan, low molecular weight hyaluronan has cytokine-like properties, and induces inflammatory gene expression in epithelial cells, endothelial cells, fibroblasts, dendritic cells and macrophages. These effects are at least partially TLR4-dependent, as shown in studies using a TLR4 blocking antibody and TLR4-deficient mice $[44,45]$. Because the disruption of basement membranes is typically associated with injury, recognition of low molecular weight hyaluronan by TLR4 and other receptors is part of an injury recognition system.

Heat shock proteins HSPs are remarkably conserved proteins in all living organisms. Their expression is induced in response to a variety of physiological and environmental insults. In the cytosol, these proteins play an essential role as molecular chaperones by assisting the correct folding of nascent and stress-accumulated misfolded proteins, preventing protein aggregation, facilitating transport of proteins, and supporting antigen processing and presentation. Following stress, intracellular HSPs fulfill protective functions and thus prevent lethal damage. By contrast, membrane-bound or extracellular HSPs act as danger signals and elicit immune responses mediated by either the adaptive or innate immune system.

HSPs 60 and 70 are two HSPs that elicit potent inflammatory responses in cells of the innate immune system, which are dependent on functional TLR4. Mouse or human macrophages and endothelial or smooth muscle cells elicit a pro-inflammatory response when incubated with recombinant human HSP60. The response includes the upregulation of adhesion molecule expression and the release of inflammatory mediators such as IL- 6 and TNF- $\alpha$, as well as IL-12 and IL-15, two cytokines that are essential in driving the $\mathrm{T}$ helper (Th)1 response. Macrophages of $\mathrm{C} 3 \mathrm{H} / \mathrm{HeJ}$ mice carrying a mutant TLR4 are unresponsive to HSP60. Similarly, HSP70 can induce TNF- $\alpha$ production by human monocytes, which is inhibited by anti-TLR4 [49]. These findings suggest that HSP60 and HSP70 are endogenous ligands of the TLR4 complex, and that there is a role for TLRs in innate immune discrimination of normal versus stressed or damaged tissue cells.

Saturated fatty acids Lipid A, which possesses most of the biological activities of LPS, is acylated with saturated fatty acids (SFAs). Removal of these acylated SFAs from lipid A not only results in complete loss of endotoxic activity, but also makes the deacylated lipid A act as an antagonist to native lipid A, suggesting that the FAs that are acylated in lipid A play a crucial role in ligand recognition and receptor activation for TLR4.

Lee et al. [11,46] showed that an SFA (lauric acid), but not unsaturated FAs, could induce NF- $\kappa \mathrm{B}$ activation and COX-2 expression. This effect is mediated through the TLR4-PI3K-AKT signaling pathway, as the induction of inflammatory markers was also inhibited by a dominantnegative mutant of TLR4, MyD88, IRAK-1, TRAF6 or $\mathrm{I} \kappa \mathrm{B} \alpha$ in macrophages (RAW264.7) and 293T cells transfected with TLR4 and MD2, and the NF- $\kappa$ B activation was inhibited by the AKT inhibitor LY294002, and by dominant-negative PI3K or AKT. Lauric acid also upregulates the expression of co-stimulatory molecules (CD40, CD80 and CD86), major histocompatibility complex (MHC) class II molecules, and cytokines (IL-12p70 and IL-6) in bone marrow (BM)-derived dendritic cells (DCs). The dominant-negative mutant of TLR4 or its downstream signaling components can inhibit lauric acid-induced expression of a CD86 promoter reporter gene. By contrast, an n-3 polyunsaturated FA (docosahexaenoic acid), inhibits TLR4 agonist (LPS)-induced upregulation of the co-stimulatory molecules, MHC class II molecules, and cytokine production. Similarly, DCs treated with lauric acid show increased T-cell activation capacity, whereas docosahexaenoic acid inhibits T-cell activation induced by LPS-treated DCs [62]. Studies using a co-culture system of adipocytes and macrophages $(\mathrm{C} 3 \mathrm{H} / \mathrm{HeN}$ and $\mathrm{C} 3 \mathrm{H} / \mathrm{HeJ}$ peritoneal macrophages, RAW264 macrophages) showed that SFA released from hypertrophied adipocytes via the macrophage-induced adipocyte lipolysis serve as a naturally occurring ligand for TLR4, thereby inducing the inflammatory changes in both adipocytes and macrophages through NF- $\kappa \mathrm{B}$ activation $[63,64]$.

These results imply that TLR4 is involved in sterile inflammation and immune responses induced by non- 
microbial endogenous molecules. These findings shed new light on how different types of dietary FAs differentially modulate immune responses that could alter the risk of many chronic diseases [11,46,62-64]. However, controversy exists about whether FA-induced TLR4 activation might be due to artifacts such as contamination by LPS of the FA preparations [65]. In addition, several lipoproteins such as low-density lipoprotein might be shuttle molecules for LPS; thus, it is possible that TLR4 activation in the in vivo models of obesity is stimulated by LPS bound to FFAs.

\section{TLR4 signaling in liver cells}

Compared with other organs, healthy liver contains low mRNA levels of TLRs and signaling molecules such as MD2 and MyD88, which may account for the high tolerance of the liver to TLR ligands from the intestinal microbiota, to which the organ is constantly exposed. Damaged liver has increased expression of TLR4 and its co-receptors, which sensitize the inflammatory cascade mediated by TLR4 signaling in the injured organ [66]. In liver, TLR4 is expressed by both the hepatocytes and non-parenchymal cells (NPCs), including liver sinusoidal endothelial cells (LSECs) and Kupffer cells (KCs). NPCs display a cell type-specific activation profile in response to the stimulation by TLR ligands [67].

\section{Hepatocytes}

Hepatocytes fulfill metabolic and detoxifying functions in the liver, and are important mediators of the acute phase response. Hepatocytes express TLR4, and respond to LPS by inducing serum amyloid A, cytochrome P450, superoxide dismutase activity, adhesion molecule, TNF$\alpha$, IL-6 and LBP. However, this response is fairly weak, with only twofold elevated levels of serum amyloid A and a less than twofold induction of most upregulated genes in a microarray after administration of LPS. Moreover, LPS doses of $100 \mathrm{ng} / \mathrm{ml}$ and higher are required to elicit significant effects in hepatocytes.

Hepatocytes play a major role in the uptake of LPS and its removal from the systemic circulation, by secreting LPS into the bile. The uptake of LPS by hepatocytes in vivo is through a CD14-TLR4-MD2-dependent mechanism, and is mediated by $\beta 2$-integrin-induced p38 MAPK activation $[32,68]$. Endogenous TLR4 ligands such as extracellular HSP72, a strongly stress-inducible 72-kDa protein that is released during ischemia-reperfusion injury (IRI), can stimulate hepatocytes to produce MIP-2, IL- 6 and TNF- $\alpha$ via TLR4-NF- $\kappa$ B-dependent signaling [69]. Studies of KC depletion in transgenic mice expressing the hepatocyte-specific hepatitis $\mathrm{C}$ virus ( $\mathrm{HCV}$ ) nonstructural protein NS5A suggest that hepatocytes can be the primary cellular site of both TLR4 upregulation and its pathologic consequences in HCV infection [70].

\section{Kupffer cells (KCs)}

$\mathrm{KCs}$ are the resident macrophages of the liver. They play a crucial role in host defense, which is linked to the ability of these cells to phagocytose, process and present antigen. KCs also secrete various pro-inflammatory mediators including cytokines, prostanoids, nitric oxide and reactive oxygen intermediates.

$\mathrm{KCs}$ are among the first cells in the liver to be exposed to gut-derived toxins such as LPS, and they orchestrate the inflammatory responses within the liver. KCs express TLR4 and respond to LPS by producing pro-inflammatory cytokines (for example, TNF- $\alpha$, IL- $1 \beta$, IL-6) and ROS (for example, superoxide and nitric oxide) [67]. Notably, KCs mediate the majority of cytokine and chemokine expression in liver after LPS injection. LPS stimulates TLR4 on KCs to enhance hepatocyte damage, increase leukocyte infiltration and secrete pro-fibrogenic cytokines. Moreover, KCs stimulated by TLR1, 2, 4 and 6 can activate allogenic $\mathrm{T}$ cells. By contrast, freshly isolated human KCs secrete the anti-inflammatory cytokine IL-10 in response to stimulation with LPS, which contributes to the downregulation of pro-inflammatory cytokines. Thus, KCs may have a higher LPS tolerance to adapt to the special circumstances in their anatomical location, in which they frequently encounter low levels of LPS even under normal conditions.

\section{Hepatic stellate cells (HSCs)}

HSCs are the predominant ECM-producing cell type in the liver. Apart from the important fibrogenic activity of HSCs, the cells have emerged as key effectors of the liver's inflammatory response, rather than being simply targets of inflammation.

Another important property of activated HSCs is their resistance to pro-apoptotic stimuli. Induction of HSC apoptosis has been proposed as a strategy to treat liver fibrosis. Activated human HSCs express LPS-recognizing receptors such as CD14, TLR4 and MD2, and they have intact TLR4 signaling. Activated HSCs respond to even low concentrations of LPS with the activation of IKK$\mathrm{NF}-\kappa \mathrm{B}$ and $\mathrm{JNK}$, secretion of pro-inflammatory cytokines (IL-6, IL-8 and TNF- $\alpha$ ), chemokines (MCP-1, MIP-2, ICAM-1, RANTES (regulated upon activation, normal T cell expressed and secreted) and C-C chemokine receptor (CCR)5), and expression of adhesion molecules [10,71]. In addition, an anti-apoptotic effect of TLR4 signaling has been reported in macrophages, cancer cells and HSCs. NF- $\kappa$ B, MAPK and PI3K/Akt signaling and downstream cytokines (for example, IL-6) and anti-apoptotic proteins (for example, Bcl-2) elicited by TLR4 activation play an active role in HSC survival [72]. Moreover, TLR4 signaling in HSCs may be more important than in KCs in mediating fibrogenesis, in part by downregulation of the 
inhibitory TGF- $\beta 1$ pseudoreceptor, BAMBI $[20,31]$. Chimeric mice with TLR4 mutant KCs show the same degree of hepatic inflammation and fibrosis as their wildtype counterparts, whereas mice with TLR4 mutant HSCs, but wild-type TLR4 KCs, show a similar resistance to experimental fibrosis as do TLR4 mutant $\mathrm{C} 3 \mathrm{H} / \mathrm{HeJ}$ mice, indicating the crucial role of TLR4 expression on HSCs. HSCs, in addition to KCs, may be a target for LPS-induced liver injury, and provide a direct link between inflammatory and fibrotic liver injury. The direct regulation of HSC gene expression by LPS represents a novel mechanism for hepatic injury and fibrosis.

\section{Liver sinusoidal endothelial cells (LSECs)}

Similar to liver macrophages, LSECs are highly responsive to acute endotoxemia, with induction of iNOS, COX-2, IL-1 $\beta$, TNF- $\alpha$ and 5-lipoxygenase genes. This activity is largely dependent on TLR4 [73]. In culture, LSECs respond to ligands of TLR1, 2, 3, 4, 6, 8 and 9 by producing TNF- $\alpha$, to ligands of TLR3 and 4 by producing IL-6, and to TLR3 ligands by producing IFN- $\beta$ [67]. LPS decreases vitamin K-dependent protein (P)S expression in hepatocytes and LSECs, which is mediated by MEK-ERK signaling and NF- $\kappa$ B activation, with the involvement of membrane-bound CD14 and TLR4 [74].

\section{Biliary epithelial cells}

The biliary tract directly communicates with the intestinal tract, and is therefore directly exposed to microorganisms from the gut. Human cholangiocytes or (biliary epithelial cells; BECs) express all 10 known TLRs, and activation of TLRs triggers an array of epithelial defense responses, including production and release of cytokines or chemokines (for example, TNF- $\alpha$, MCP-1, IL- 6 and IL-8) and anti-microbial peptides [75-77]. TLR2 and TLR4 signaling mediate cholangiocyte responses, including production of human $\beta$-defensin 2 against $C$. parvum via TLR-associated activation of NF- $\kappa$ B. Human cholangiocytes express members of the let-7 miRNA family, at least one of which, let-7i, directly regulates TLR4 expression via a MyD88-NF- $\kappa$ B-dependent mechanism. Following microbial insult, cholangiocytes decrease let-7i expression and consequently upregulate TLR4 expression via translational suppression in infected cells, which contributes to epithelial immune responses to microbial infection [37]. Endotoxin tolerance is present within the intrahepatic biliary tree, which is important in maintaining innate immune biliary homeostasis. The tolerance is possibly induced by the expression of IRAK-M in the intrahepatic biliary epithelium [78].

\section{Hepatic dendritic cells (DCs)}

DCs are classic antigen-presenting cells that present peripheral antigens to $\mathrm{T}$ cells in lymph nodes, regulate
$\mathrm{T}$ cell differentiation (tolerance or immunity, Th1 or Th2 polarization) and initiate specific immune responses. Their maturation is vital for the induction of antigen-specific T-lymphocyte responses. DCs express TLRs, and as a result of TLR triggering, DCs upregulate co-stimulatory molecules, secrete immunomodulatory cytokines such as IL-12, and increase antigen processing and presentation to $\mathrm{B}$ and $\mathrm{T}$ lymphocytes. Thus, TLRs function to alert the immune system to infection by stimulating DCs, which act as a bridge between the innate and adaptive immune systems.

Liver DCs exhibit a comparatively high threshold for stimulation by LPS, which may be explained by their low expression of TLR4. This unresponsiveness can be at least partially overcome by high LPS levels that exceed those encountered in the absence of clinical infection [79]. LPS-mediated TLR4 signaling leads to maturation of DCs [80]. Hepatic DCs respond to TLR1, 2, 4 and 9 ligands by both upregulation of CD40 and activation of allogeneic T cells. TLR3 and TLR4 stimulation in DCs induces co-stimulatory molecules and cytokines [67]. In a mouse model of diabetes, HMGB1 upregulates $\mathrm{CD} 40$ expression and enhances IL-12 production by DCs, leading to natural killer (NK)T cell activation and subsequent NKT cell-dependent augmentation of IFN- $\gamma$ production, with the early loss of transplanted islets [81]. AM3, a mixture containing immunoregulatory glycoconjugates, induces functional maturation of monocyte-derived DCs from patients with chronic HCV infection and healthy donors, and stimulates the secretion of molecules with antiviral properties in a TLR4-dependent manner [82].

\section{Lymphocytes}

Lymphocytes constitute $25 \%$ of the non-parenchymal resident cells in the normal human liver, and the subpopulations differ numerically according to normal conditions or the existence of stresses such as inflammation and steatosis [83]. TLRs are widely expressed by immune cells, including $\mathrm{T}$ and $\mathrm{B}$ lymphocytes. Conventional CD4+ T helper cells, cytotoxic $\mathrm{T}$ lymphocytes (CTL) and naturally arising regulatory $\mathrm{T}$ cells (Tregs) all express TLRs. TLR triggering on innate immune cells results in the induction of pro-inflammatory cytokines, phagocytosis and subsequent innate effector mechanisms, including an oxidative burst [84].

CD4+ CD25+ Foxp3+ Tregs, a key player in maintaining peripheral $\mathrm{T}$ cell tolerance [85], express TLR4 and other TLRs. Direct engagement of TLR4 by LPS on Tregs upregulates several activation markers, and induces Treg proliferation or survival without the need for TCR ligation. More importantly, LPS-treated Tregs exert enhanced function in vitro and remain suppressive in vivo [86]. Regulation of Treg function via TLRs 
constitutes an important immunosuppressive cellular mechanism to curtail TLR hyperactivity, thereby avoiding sepsis and autoimmune diseases [87].

\section{TLR4 signaling in liver injury}

TLR4 signaling is a 'good' response in promoting pathogen eradication and initiating liver regeneration. It is essential in the generation of both innate and adaptive immune responses against pathogens (for example, salmonella) [88]. TLR4-deficient $\mathrm{C} 3 \mathrm{H} / \mathrm{HeJ}$ mice have an increased microbial burden and mortality after infection [88].

However, TLR4 also plays a deleterious role in hepatic inflammation and injury arising from many causes (Figure 2). TLR activation induces pro-inflammatory cytokine cascades, which contribute to the pathophysiology and clinical outcome of severe liver injuries. Genetic deletion or mutation of TLR4 reduces macrophage infiltration and liver injuries in animals with experimentally induced liver damage.

\section{Drug-induced liver diseases}

TLR4 is involved in the generation of steatosis, congestion and necrosis from paracetamol (acetaminophen; APAP) [89] through release of inflammatory cytokines (TNF- $\alpha$ ), induction of iNOS and peroxynitrite, and depletion of glutathione. These events occur in response to LPS and possibly endogenous ligands released from the ECM during chemical or mechanical injury. Such injuries can further amplify systemic inflammatory immune responses by enhancing TLR4 reactivity, and

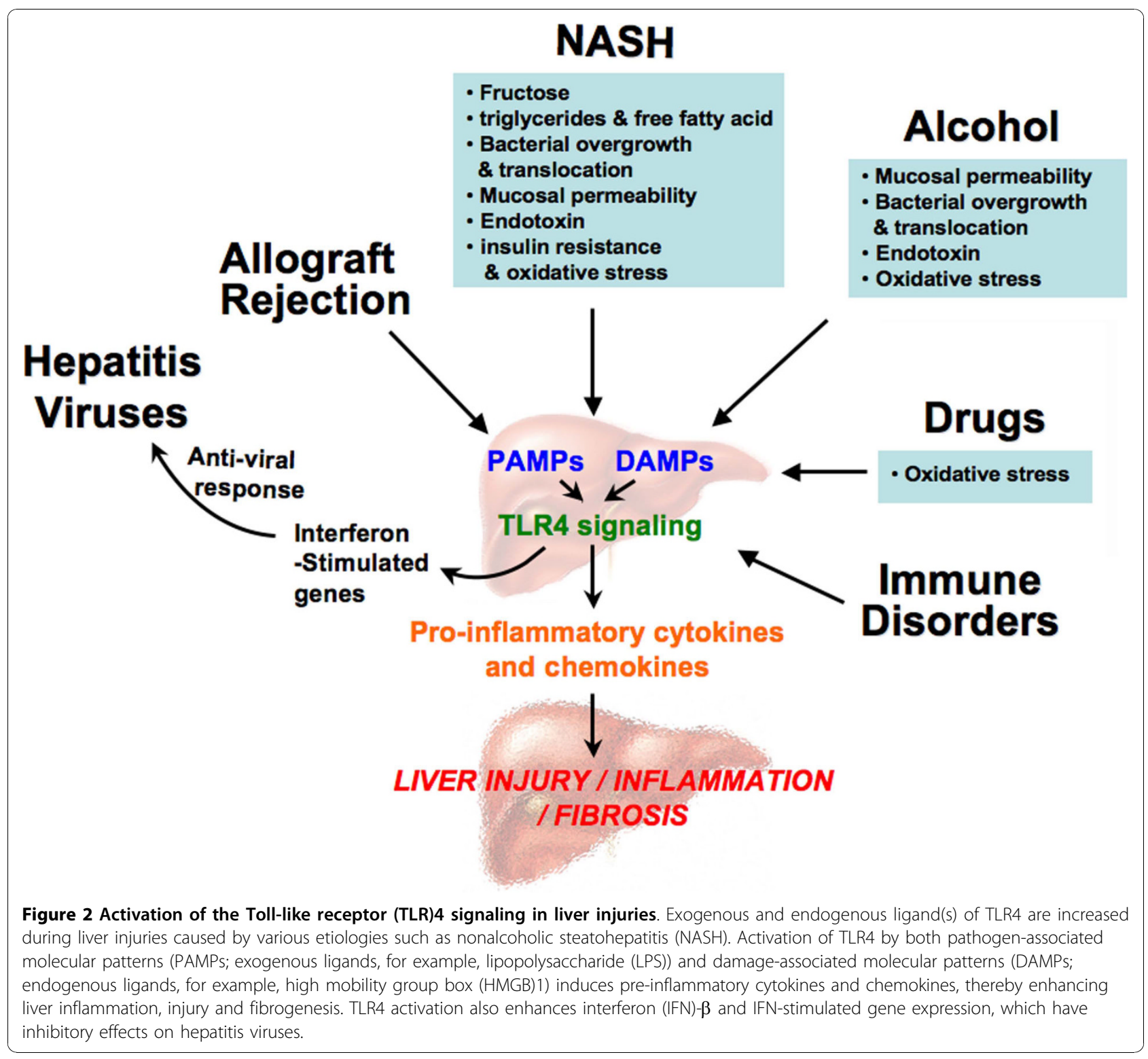


can also result in leukocyte sequestration along with increased pro-inflammatory cytokine and chemokine levels. Serum hyaluronic acid is elevated in APAPmediated liver injury in humans, and has been proposed as a prognostic indicator of survivability after APAP overdose $[90,91]$.

\section{Viral hepatitis}

Components of hepatitis viruses are ligands for TLR3, TLR7, TLR8 and TLR9, but not for TLR4. However, innate immune responses induced by TLR4 signaling may antagonize anti-hepatitis B virus (HBV) infection in vivo through the induction of IFN- $\alpha / \beta$, iNOS and HBVspecific immune responses.

Several TLRs, including TLR4, block HBV replication through their ability to upregulate IFNs [92]. Similarly, in vitro studies indicate that activation of TLR3 and TLR4 by their ligands in non-parenchymal liver cells (in particular KCs and LSECs) is able to induce IFN- $\beta$ - and IFN-stimulated genes, which leads to potent suppression of HCV replication $[67,93]$. TLR4 is upregulated in the hepatocytes of patients with chronic HBV, indicating a potentially important interaction. TLR4 and TLR6 are downregulated in HBV-infected peripheral blood monocytes, and these cells also have a decreased cytokine response to TLR2 and TLR4 ligands. By contrast, TLR4 expression is increased in the peripheral blood monocytes of patients with chronic $\mathrm{HCV}$, along with increased cytokine production, including that of IFN- $\beta$, TNF- $\alpha$, IL- 6 and IL- 8 . The number of Tregs is significantly higher in these patients, which correlates with HCV genotype and viral load [94,95]. The HCV nonstructural protein (NS)5A and alcohol synergistically induce hepatocellular damage and transformation via amplified and/or sustained activation of TLR4 signaling, with the induction of Nanog downstream of TLR4 signaling. Induction of this stem cell marker may contribute to $\mathrm{HCV}$-induced liver oncogenesis enhanced by alcohol [70].

\section{Non-alcoholic fatty liver diseases}

Obesity, insulin resistance (IR) and oxidative stress are major pathogenetic determinants of non-alcoholic fatty liver disease (NAFLD). Insulin receptor-mediated tyrosine phosphorylation of insulin receptor substrates (IRS) leads to the activation of downstream pathways (PI3K/ AKT and MAPK) responsible for insulin action on glucose uptake and suppression of gluconeogenesis, cell growth and differentiation. Inflammatory cytokines such as TNF- $\alpha$ and IL-1 interfere with insulin signaling by provoking IRS serine phosphorylation and thus inactivate its activity in insulin signaling, causing IR [96]. Production of IL- 6 or TNF- $\alpha$ also blunts insulin signaling in hepatocytes and muscle by increasing suppressor of cytokine signaling (SOCS)1, SOCS3 and nitric oxide (NO).

There is a vicious circle of aggravating IR based on hepatic steatosis and inflammation. IR leads to increased circulating FFA concentration and ectopic fat accumulation, which impede insulin-mediated glucose uptake in skeletal muscle and elevate glucose production in liver. By contrast, TLR4 on adipocytes and macrophages is a sensor of elevated FFA concentrations, which initiates inflammatory and thus insulin-desensitizing processes, leading to the development of NAFLD. Fatty acids, in particular SFAs, utilize TLR4 to induce NF- $\kappa$ B activation and pro-inflammatory cytokine expression in macrophages, adipocytes, vascular endothelial cells and liver.

TLR4 is a molecular link between nutrition, lipids and inflammation [97]. Triglycerides potentiate the inflammatory response of KCs to LPS in producing inducible NOS, TNF- $\alpha$, IL- $1 \beta$, IL- 6 and granulocyte colony-stimulating factor in vitro [98]. Dietary fructose intake is also associated with NAFLD. Intake of high levels of fructose results in high triglyceride levels in plasma and their deposition in liver, as well as intestinal bacterial overgrowth and increased intestinal permeability, leading to elevated endotoxins and activation of TLR4 signaling $[99,100]$.

\section{Alcoholic steatohepatitis}

In alcoholic liver disease, endotoxemia may play a primary role in the induction of liver damage as a consequence of activating TLR4 signaling, thereby initiating an inflammatory cascade in liver cells [101]. Ethanol increases the circulating levels of gut-derived endotoxin, as a result of alteration of gut permeability, modification of the gut flora and changes in the rates of endotoxin clearance [102]. Alcohol induces LBP and TLR4, and increases responsiveness to gut-derived endotoxin. Binding of LPS to CD14/TLR4 on KCs activates production of cytokines and oxidants, primary mediators of early ethanol-induced liver injury. Furthermore, cytokine and oxidant production lead to T cell recruitment, HSC activation and collagen production in the liver of patients with alcoholic steatohepatitis [103]. Antibiotics and lactobacilli reduce liver injury in animals chronically fed alcohol.

\section{Autoimmune liver diseases}

In primary biliary cirrhosis, TLR4 is expressed in bile duct epithelial cells and periportal hepatocytes, and may be involved in the inflammation and tissue destructive process of bile ducts and the interface hepatitis of primary biliary cirrhosis (PBC) [104]. These findings indicate that bacterial pathogens and TLR4 may contribute to the inflammatory response in PBC. 
Stimulation of BECs with primary sclerosing cholangitis IgG, but not control IgG, induces expression of TLR4 and TLR9, and specific phosphorylation of both ERK, and the transcription factors ELK-1 and NF- $\kappa$ B. In BECs, a specific inhibitor of ERK1/2 abrogates phosphorylation of ELK-1 and protein expression of TLR4 but not TLR9 [105].

\section{Ischemia-reperfusion injury (IRI)}

IRI occurs in solid organ transplantation, hemorrhagic shock, diverse surgical procedures, and heart failure. It is defined as an ischemic insult that induces delayed dysfunction and damage due to activation of inflammatory pathways, in which the TRL4 signaling pathway appears to be crucial. IRI induces a biphasic pattern of liver injury, with an acute phase occurring within the first 6 hours of reperfusion, characterized by a burst of pro-inflammatory cytokines and formation of ROS. This is followed by a late phase from 6 to 24 hours after ischemia, characterized by sequestration of neutrophils into the liver.

IRI is a tightly coordinated and sequential process mediated by the integration of both innate and adaptive immune reactions. TLR4 signaling by non-parenchymal cells is required for initiation of hepatic IRI [106,107]. Analysis of TLR4 chimeric mice with hepatic IRI indicates that mutation of TLR4 within either BM-derived or non-BM-derived TLR4 reduces hepatic IRI in the late reperfusion stage via reduced cytokine release and neutrophil infiltration, whereas non-BM-derived TLR4 regulates the expression of ICAM-1 on hepatocytes and LSECs, exacerbating the injury [108]. TLR4 signaling is also a putative repressor of heme oxygenase-1, which is cytoprotective and antioxidative in hepatic IRI [109].

\section{Allograft rejection after liver transplantation}

Although continuous improvements in immunosuppression and clinical management have contributed to increased graft survival, acute rejection remains common after liver transplantation ( 25 to $49 \%$ of cases). The innate immune response, which is important in regulating the quality of the adaptive immune response, plays a prominent role in immune recognition of solid organ allografts. The family of TLRs is expressed on a variety of cell types, including antigen-presenting, epithelial and endothelial cells.

TLRs are a crucial link in activating dendritic cell maturation programs that induce adaptive immune responses. TLRs may be activated by some endogenous agonists, thereby participating in allograft responses. Significantly higher TLR4 and TLR2 expression is present on circulating monocytes in recipients of liver transplantation with acute rejection, compared with those who are clinically stable with normal liver function. Thus, elevated
TLR2 and TLR4 may be candidates for early prediction of acute rejection after liver transplantation [110].

There are differential effects of donor and recipient TLR4 signaling in human liver transplantation. Donor TLR4 contributes to sterile injury after cold preservation, whereas the recipient TLR4 genotype is linked to poor allograft survival among $\mathrm{HCV}$-infected recipients [111]. Myeloid dendritic cells (MDCs) of donor origin detached from liver grafts that migrate into the recipient express higher levels of TLR4 than do blood or splenic MDCs. These MDCs are sensitive to stimulation with physiological concentrations of LPS, produce proinflammatory and anti-inflammatory cytokines, and are capable of stimulating allogeneic Th1 responses. Thus, MDCs may contribute to liver graft rejection rather than tolerance [112].

\section{Cirrhosis}

TLR4 regulation is altered in monocytes from patients with cirrhosis. Under normal conditions, monocytes release pro-inflammatory mediators such as TNF- $\alpha$, IL1 and IL- 6 in response to LPS stimulation, which promote systemic inflammatory reactions including fever and leukocytosis. Patients with cirrhosis have chronic endotoxinemia, with elevated serum levels of TNF- $\alpha$, IL- $1 \beta$ and IL- 6 due to activated KCs and decreased hepatic clearance. Patients with cirrhosis also lack both LPS-mediated upregulation of pro-inflammatory cytokines by peripheral blood mononuclear cells and systemic reactions such as fever and leukocytosis, whereas bacterial infections are extraordinarily frequent. Patients with cirrhosis also have a higher basal level of TLR4 expression, which is induced upon LPS stimulation and is persistently upregulated after $24 \mathrm{~h}$ of incubation with LPS [113].

\section{TLR4 signaling and liver fibrogenesis}

\section{Important link between TLR4 signaling and enhanced fibrogenesis}

Fibrosis is characterized by an excessive deposition of ECM protein, impairing normal liver function, and ultimately leading to cirrhosis and organ failure. Inflammation and tissue injury are important factors that initiate and promote liver fibrosis [114-116]. Chronic inflammation and fibrogenesis are a dynamic aggregate of lymphocytes, macrophages and stromal cells linked by autocrine and paracrine interactions [117]. Inflammatory cells belonging to the innate (for example, NK cells and macrophages) and adaptive immune response ( $\mathrm{T}$ and $\mathrm{B}$ cells) participate in liver injury and fibrogenesis. TLR signaling in the course of liver injury by hepatitis viruses and other etiologies contributes significantly to the activation and interaction of inflammatory cells, myofibroblasts and the matrix microenvironment. 
TLR4 signaling is activated in acute infection to clear the pathogen, but contributes to liver scarring in chronic disease. TLR4 and its ligands mediate their effects in liver fibrosis through different mechanisms. First, TLR4 downregulates the TGF- $\beta 1$ pseudoreceptor BAMBI to sensitize HSCs to TGF- $\beta 1$-induced signals [20]. Second, TLR4 activation also upregulates cytokine and chemokine secretion from cells with inflammatory phenotypes such as KCs and HSCs $[10,72,88,118]$
(Figure 3). HSCs act as important effectors of the liver's inflammatory response by regulating leukocyte trafficking and $\mathrm{KC}$ recruitment and activation via secretion of cytokines and chemokines $[119,120]$.

TLR4 was identified as one of seven genes associated with increased risk of developing cirrhosis in patients with chronic hepatitis C [72,121]. LPS and endogenous TLR4 ligands are increased in the serum and livers of patients with liver cirrhosis and of animals with

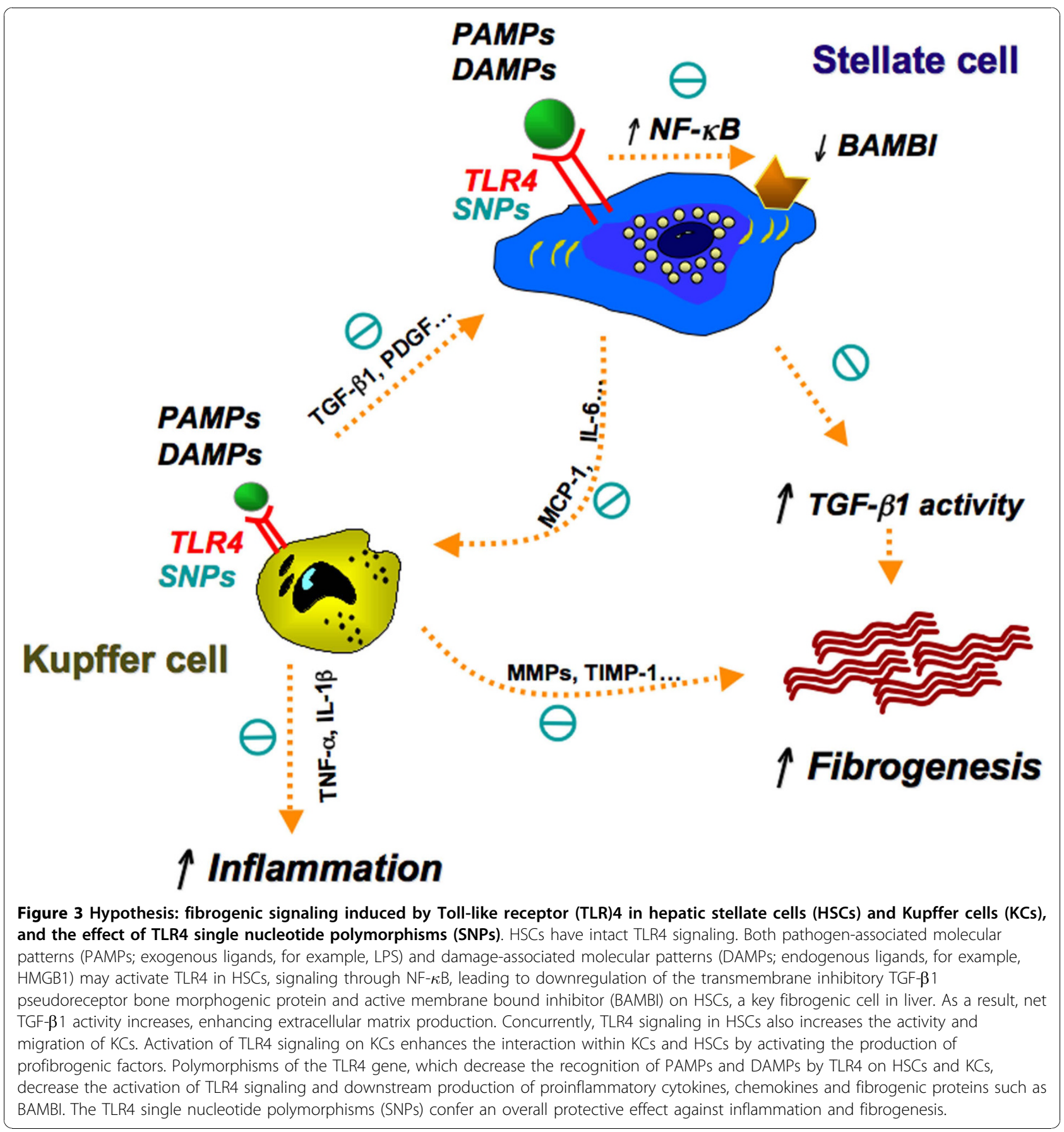


experimental chronic liver disease. CD14- or LBP-deficient mice are resistant to the liver injury and fibrosis induced by bile duct ligation [122]. Studies using TLR4 mutant $\mathrm{C} 3 \mathrm{H} / \mathrm{HeJ}$ mice have demonstrated that hepatic inflammation and fibrosis are strongly decreased in the TLR4 mutant $\mathrm{C} 3 \mathrm{H} / \mathrm{HeJ}$ strain after bile duct ligation or carbon tetrachloride administration [20]. The cellular mechanisms underlying the fibrosis-promoting effects of TLR4 in the liver are not yet elucidated.

\section{TLR4 polymorphisms and the functional consequences on liver fibrosis}

SNPs of TLRs influence the vigor of immune responses in bacterial, viral and parasitic infections. More than 100 SNPs have been identified in human TLR4 genes, of which the TLR4 T399I and D299G are two common (frequency 0 to $20 \%$ across different ethnicities), highly co-segregated ( $80 \%$ co-segregation rate), non-synonymous polymorphisms within the extracellular domain of the TLR4 protein. These SNPs may affect the strength of interactions with either agonist(s) and/or coreceptors, leading to decreased recognition of ligands in an agonist-independent manner [123-125]. These TLR4 SNPs are primarily associated with a blunted response to inhaled LPS in humans [126]. Many studies report the association between these TLR4 genetic polymorphisms and disease risk. They are associated with susceptibility to infectious diseases including Gram-negative bacterial infection $[127,128]$, severe malaria [129], bronchitis [130-132], and diseases as disparate as inflammatory bowel disease [130], early onset pre-eclampsia [133], Helicobacter pylori infection, and gastric cancer [134]. TLR4 SNPs reduce the risk of early acute allograft rejection. They are not associated with the risk or severity of either rheumatoid arthritis or systemic lupus erythematosus [135-138]; multiple sclerosis [139,140]. spondylarthropathies [141], cerebral ischemia [142], juvenile idiopathic arthritis [143]; and outcome of angiography [144].

In contrast to the reduced risk of early acute allograft rejection $[111,145]$, TLR4 SNPs are associated with delayed progression of hepatic fibrosis $[121,146]$. A genecentric functional genome scan in patients with chronic hepatitis $\mathrm{C}$ yielded a Cirrhosis Risk Score (CRS) signature consisting of seven SNPs that may predict the risk of developing cirrhosis [121]. Of these seven SNPs, the major CC allele of TLR4 encoding p.T399 is the second most predictive SNP. This allelle confers a threefold increased risk of fibrosis progression over carriers of the T399I variant, indicating a protective role in fibrosis progression of the c.1196C $\rightarrow \mathrm{T}$ (rs4986791) variant at this location (p.T399I), along with another highly co-segregated SNP, c.896A $\rightarrow$ G (rs4986790), located at coding position 299 (p.D299G). Absence of TLR4 or expression of the TLR4 T399I and/or D299G SNPs confers reduced LPS responsiveness in cultured human or mouse HSCs [72]. These SNPs reduce NF- $\kappa$ B activation and pro-inflammatory cytokine expression, and attenuate downregulation of the TGF- $\beta$ pseudoreceptor BAMBI in HSCs after LPS stimulation. These SNPs also reduce cell growth and lower the apoptotic threshold in mouse hepatic stellate cells after apoptotic stress [72]. In addition to these two missense variants, other variants of the TLR4 gene have also been independently associated with the risk of fibrosis by dense genotyping and association testing, findings that warrant further mechanistic studies [146]. Thus, although specific SNPs confer LPS hyporesponsiveness and increased susceptibility to infection, they reduce the likelihood of end-organ damage due to progressive scarring. Further studies are needed to explore if these SNPs also affect fibrogenesis through responses in other cell types and if they affect the response of TLR4 to endogenous ligands (Figure 3).

\section{Future prospects}

Because TLR4 signaling has been identified as a key inflammatory and fibrogenic signal in injured liver and HSCs, interventions to inhibit the intracellular signaling associated with TLR4-IL-1R might be effective in reducing the inflammatory actions of TLR4-mediated liver injury and dampening liver fibrogenesis [147]. A peptide termed P13 limits the LPS-induced inflammatory response and enhances survival in murine models of inflammation [148]. Pharmacological inhibition of endotoxin responses has also been achieved by targeting the TLR4 co-receptor, MD2 [149]. Several small molecule inhibitors of TLR4 are currently being tested, including:

(1) Lipid A mimetics (for example, E5564 and CRX$526[150,151])$ which bind to the TLR4-MD2 complex but lack intrinsic activity and thus prevent binding of the lipid A portion of LPS and subsequent TLR4 activation

(2) TAK-242, which exerts its inhibitory effects at the intracellular domain of TLR4 [152]. Both E5564 and TAK-242 are currently being tested in phase III clinical trials in patients with septic shock.

(3) Soluble fusion proteins of the extracellular domain of TLR4 and MD2 or TLR4/MD2/IgG-Fc fusion protein that bind LPS. They specifically inhibit LPS-induced NF- $\kappa \mathrm{B}$ and JNK activation, and abolish LPS-induced secretion of chemokines (MCP-1) and cytokines (IL-6) from HSCs [153]. This soluble receptor might provide a new biologic agent in the prevention and therapy of liver fibrosis and other diseases in which TLR4-mediated signal transduction plays a pathological role, such as in alcoholic liver injury and non-alcoholic steatohepatitis.

(4) Fc/fusion protein or antagonists of TREM-1 (triggering receptor expressed on myeloid cells-1), which 
belongs to another pattern recognition receptor family. This molecule synergizes with TLR4, and mediates the inflammatory responses of hepatic macrophages and endothelial cells to LPS. Blockage of TREM-1 limits LPS-induced inflammatory responses and injury [154].

By contrast, synthetic TLR4 agonists may boost the protective innate immune responses against infection [155]. Examples include alpha-1 acid glycoproteins, which are a class of lipid A mimetics composed of a monosaccharide unit with an $\mathrm{N}$-acylated aminoalkyl aglycon spacer arm. Increasing evidence suggests that immune modulators such as TLR4 ligands or agonists could also be successfully used as therapeutic agents in infectious liver diseases, such as $\mathrm{HBV}$ and $\mathrm{HCV}$ $[93,156]$.

\section{Acknowledgements}

This study was supported by NIH Grant RO1DK56621 and funding from Celera Diagnostics. JG is a recipient of National Fund of Nature Science of P. R. China (Number 81070340)

\section{Author details}

'Division of Digestive Diseases, Zhong Shan Hospital, Department of Internal Medicine, Shanghai Medical College, Fu Dan University, Shanghai, China. ${ }^{2}$ Division of Liver Diseases, Mount Sinai Hospital, Mount Sinai School of Medicine, New York, NY, USA.

\section{Authors' contributions}

JG wrote the initial draft of the manuscript and figures. SLF finalized the manuscript and provided guidance into its organization and figures. All authors read and approved the final manuscript.

\section{Competing interests}

The authors declare that they have no competing interests.

Received: 7 September 2010 Accepted: 21 October 2010 Published: 21 October 2010

\section{References}

1. Rock FL, Hardiman G, Timans JC, Kastelein RA, Bazan JF: A family of human receptors structurally related to Drosophila Toll. Proc Natl Acad Sci USA 1998, 95:588-593.

2. Medzhitov R, Preston-Hurlburt P, Janeway CA: A human homologue of the Drosophila Toll protein signals activation of adaptive immunity. Nature 1997, 388:394-397.

3. Szabo G, Dolganiuc A, Mandrekar P: Pattern recognition receptors: $A$ contemporary view on liver diseases. Hepatology 2006, 44:287-298.

4. Lu YC, Yeh WC, Ohashi PS: LPS/TLR4 signal transduction pathway. Cytokine 2008, 42:145-151.

5. da Silva Correia J, Soldau K, Christen U, Tobias PS, Ulevitch RJ: Lipopolysaccharide is in close proximity to each of the proteins in its membrane receptor complex: Transfer from CD14 to TLR4 and MD2. J Biol Chem 2001, 276:21129-21135.

6. Tissieres P, Dunn-Siegrist I, Schappi M, Elson G, Comte R, Nobre V, Pugin J: Soluble MD2 is an acute-phase protein and an opsonin for Gramnegative bacteria. Blood 2008, 111:2122-2131.

7. Fitzgerald KA, Palsson-McDermott EM, Bowie AG, Jefferies CA, Mansell AS, Brady G, Brint E, Dunne A, Gray P, Harte MT, et al: Mal (MyD88-adapterlike) is required for Toll-like receptor-4 signal transduction. Nature 2001, 413:78-83

8. Yamamoto M, Sato S, Hemmi H, Uematsu S, Hoshino K, Kaisho T, Takeuchi O, Takeda K, Akira S: TRAM is specifically involved in the Toll-like receptor 4-mediated MyD88-independent signaling pathway. Nat Immunol 2003, 4:1144-1150.
9. Hoebe K, Du X, Georgel P, Janssen E, Tabeta K, Kim SO, Goode J, Lin P, Mann N, Mudd S, et al: Identification of Lps2 as a key transducer of MyD88-independent TIR signalling. Nature 2003, 424:743-748.

10. Paik YH, Schwabe RF, Bataller R, Russo MP, Jobin C, Brenner DA: Toll-like receptor 4 mediates inflammatory signaling by bacterial lipopolysaccharide in human hepatic stellate cells. Hepatology 2003, 37:1043-1055.

11. Lee JY, Ye J, Gao Z, Youn HS, Lee WH, Zhao L, Sizemore N, Hwang DH: Reciprocal modulation of Toll-like receptor-4 signaling pathways involving MyD88 and phosphatidylinositol 3-kinase/AKT by saturated and polyunsaturated fatty acids. J Biol Chem 2003, 278:37041-37051.

12. Arndt PG, Suzuki N, Avdi NJ, Malcolm KC, Worthen GS: Lipopolysaccharideinduced c-Jun NH2-terminal kinase activation in human neutrophils: role of phosphatidylinositol 3-Kinase and Syk-mediated pathways. J Biol Chem 2004, 279:10883-10891.

13. Vogel SN, Fenton M: Toll-like receptor 4 signalling: new perspectives on a complex signal-transduction problem. Biochem Soc Trans 2003, 31:664-668.

14. McGettrick AF, O'Neill LA: Localisation and trafficking of Toll-like receptors: an important mode of regulation. Curr Opin Immunol 2010, 22:20-27.

15. Tamassia N, Le Moigne V, Calzetti F, Donini M, Gasperini S, Ear T, Cloutier A, Martinez FO, Fabbri M, Locati M, et al: The MyD88-independent pathway is not mobilized in human neutrophils stimulated via TLR4. J Immunol 2007, 178:7344-7356

16. Burstein E, Duckett CS: Dying for NF-kappaB? Control of cell death by transcriptional regulation of the apoptotic machinery. Curr Opin Cell Biol 2003, 15:732-737.

17. Elsharkawy AM, Mann DA: Nuclear factor-kappaB and the hepatic inflammation-fibrosis-cancer axis. Hepatology 2007, 46:590-597.

18. Chakraborty JB, Mann DA: NF-kappaB signalling: embracing complexity to achieve translation. J Hepatol 2010, 52:285-291.

19. Martha R, Watson KW, Roben GGieling, Derek MManas, Ellis Jaffray, Ronald T, Hay DAM, Fiona Oakley: NF-kappaB is a critical regulator of the survival of rodent and human hepatic myofibroblasts. $J$ Hepatol 2008, 48:589-597.

20. Seki E, De Minicis S, Osterreicher CH, Kluwe J, Osawa Y, Brenner DA, Schwabe RF: TLR4 enhances TGF-beta signaling and hepatic fibrosis. Nat Med 2007, 13:1324-1332.

21. Hall MC, Young DA, Waters JG, Rowan AD, Chantry A, Edwards DR, Clark IM: The comparative role of activator protein 1 and Smad factors in the regulation of Timp-1 and MMP-1 gene expression by transforming growth factor-beta 1. J Biol Chem 2003, 278:10304-10313.

22. Smart DE, Vincent KJ, Arthur MJ, Eickelberg O, Castellazzi M, Mann J, Mann DA: JunD regulates transcription of the tissue inhibitor of metalloproteinases-1 and interleukin-6 genes in activated hepatic stellate cells. J Biol Chem 2001, 276:24414-24421.

23. Bahr MJ, Vincent KJ, Arthur MJ, Fowler AV, Smart DE, Wright MC, Clark IM, Benyon RC, Iredale JP, Mann DA: Control of the tissue inhibitor of metalloproteinases-1 promoter in culture-activated rat hepatic stellate cells: regulation by activator protein-1 DNA binding proteins. Hepatology 1999, 29:839-848.

24. Chung KYAA, Uitto J, Mauviel A: An AP-1 binding sequence is essential for regulation of the human a2(I) collagen (COL1A2) promoter activity by transforming growth factor-beta. J Biol Chem 1996, 271:3272-3278.

25. Bertrand-Philippe MRR, Arhur MJP, Thomas J, Mungalsingh N, Mann DA: Regulation of tissue inhibitor of metalloproteinase 1 gene transcription by RUNX1 and RUNX2. J Biol Chem 2004, 279:24530-24539.

26. Lee KY, Ito K, Hayashi R, Jazrawi EP, Barnes PJ, Adcock IM: NF-kappaB and activator protein 1 response elements and the role of histone modifications in IL-1beta-induced TGF-beta1 gene transcription. J Immunol 2006, 176:603-615.

27. Au WC, Moore PA, Lowther W, Juang YT, Pitha PM: Identification of a member of the interferon regulatory factor family that binds to the interferon-stimulated response element and activates expression of interferon-induced genes. Proc Natl Acad Sci USA 1995, 92:11657-11661.

28. Molle C, Goldman M, Goriely S: Critical role of the IFN-stimulated gene factor 3 complex in TLR-mediated IL-27p28 gene expression revealing a two-step activation process. J Immunol 2010, 184:1784-1792. 
29. Rhee SH, Jones BW, Toshchakov V, Vogel SN, Fenton MJ: Toll-like receptors 2 and 4 activate STAT1 serine phosphorylation by distinct mechanisms in macrophages. J Biol Chem 2003, 278:22506-22512.

30. Rothfuchs AG, Trumstedt C, Wigzell H, Rottenberg ME: Intracellular bacterial infection-induced IFN-gamma is critically but not solely dependent on Toll-like receptor 4-myeloid differentiation factor 88-IFNalpha beta-STAT1 signaling. J Immunol 2004, 172:6345-6353.

31. Friedman SL: A deer in the headlights: BAMBI meets liver fibrosis. Nat Med 2007, 13:1281-1282.

32. Scott MJ, Liu S, Shapiro RA, Vodovotz Y, Billiar TR: Endotoxin uptake in mouse liver is blocked by endotoxin pretreatment through a suppressor of cytokine signaling-1-dependent mechanism. Hepatology 2009, 49:1695-1708.

33. O'Reilly SM, Moynagh PN: Regulation of Toll-like receptor 4 signalling by A20 zinc finger protein. Biochem Biophys Res Commun 2003, 303:586-593.

34. Chen F, Du Y, Zhang Z, Chen G, Zhang M, Shu HB, Zhai Z, Chen D: Syntenin negatively regulates TRAF6-mediated IL-1R/TLR4 signaling. Cell Signal 2008, 20:666-674.

35. Gilchrist M, Thorsson V, Li B, Rust AG, Korb M, Roach JC, Kennedy K, Hai T, Bolouri H, Aderem A: Systems biology approaches identify ATF3 as a negative regulator of Toll-like receptor 4. Nature 2006, 441:173-178.

36. Suganami T, Yuan X, Shimoda Y, Uchio-Yamada K, Nakagawa N, Shirakawa I, Usami T, Tsukahara T, Nakayama K, Miyamoto Y, et al: Activating transcription factor 3 constitutes a negative feedback mechanism that attenuates saturated Fatty acid/Toll like receptor 4 signaling and macrophage activation in obese adipose tissue. Circ Res 2009, 105:25-32.

37. Chen XM, Splinter PL, O'Hara SP, LaRusso NF: A cellular micro-RNA, let-7i, regulates Toll-like receptor 4 expression and contributes to cholangiocyte immune responses against Cryptosporidium parvum infection. J Biol Chem 2007, 282:28929-28938.

38. Lee RC, Feinbaum RL, Ambros V: The C. elegans heterochronic gene lin-4 encodes small RNAs with antisense complementarity to lin-14. Cell 1993, 75:843-854.

39. Ji J, Zhang J, Huang G, Qian J, Wang X, Mei S: Over-expressed microRNA$27 \mathrm{a}$ and $27 \mathrm{~b}$ influence fat accumulation and cell proliferation during rat hepatic stellate cell activation. FEBS Lett 2009, 583:759-766.

40. Georgel P, Jiang Z, Kunz S, Janssen E, Mols J, Hoebe K, Bahram S, Oldstone MB, Beutler B: Vesicular stomatitis virus glycoprotein $G$ activates a specific antiviral Toll-like receptor 4-dependent pathway. Virology 2007, 362:304-313.

41. Jude BA, Pobezinskaya Y, Bishop J, Parke S, Medzhitov RM, Chervonsky AV, Golovkina TV: Subversion of the innate immune system by a retrovirus. Nat Immunol 2003, 4:573-578.

42. Kurt-Jones EA, Popova L, Kwinn L, Haynes LM, Jones LP, Tripp RA, Walsh EE, Freeman MW, Golenbock DT, Anderson L, Finberg RW: Pattern recognition receptors TLR4 and CD14 mediate response to respiratory syncytial virus. Nat Immunol 2000, 1:398-401.

43. Guo J, Friedman S: Hepatic fibrogenesis. Semin Liver Dis 2007, 27:413-426.

44. Taylor KR, Trowbridge JM, Rudisill JA, Termeer CC, Simon JC, Gallo RL: Hyaluronan fragments stimulate endothelial recognition of injury through TLR4. J Biol Chem 2004, 279:17079-17084.

45. Jiang D, Liang J, Fan J, Yu S, Chen S, Luo Y, Prestwich GD, Mascarenhas MM, Garg HG, Quinn DA, et al: Regulation of lung injury and repair by Toll-like receptors and hyaluronan. Nat Med 2005, 11:1173-1179.

46. Lee JY, Sohn KH, Rhee SH, Hwang D: Saturated fatty acids, but not unsaturated fatty acids, induce the expression of cyclooxygenase-2 mediated through Toll-like receptor 4. J Biol Chem 2001, 276:16683-16689.

47. Smiley ST, King JA, Hancock WW: Fibrinogen stimulates macrophage chemokine secretion through Toll like receptor 4. J Immunol 2001, 167:2887-2894.

48. Okamura Y, Watari M, Jerud ES, Young DW, Ishizaka ST, Rose J, Chow JC, Strauss JF: The extra domain A of fibronectin activates Toll-like receptor 4. J Biol Chem 2001, 276:10229-10233.

49. Chen X, Sun Z, Du X, Liu C, Liu Y, Wu L: Study on the relationship between heat shock protein 70 and Toll like receptor-4 of monocytes. J Huazhong Univ Sci Technolog Med Sci 2004, 24:560-562.

50. Ohashi K, Burkart V, Flohe S, Kolb H: Cutting edge: heat shock protein 60 is a putative endogenous ligand of the Toll like receptor- 4 complex. J Immunol 2000, 164:558-561.
51. Park JS, Svetkauskaite D, He Q, Kim JY, Strassheim D, Ishizaka A, Abraham E: Involvement of Toll like receptors 2 and 4 in cellular activation by high mobility group box 1 protein. J Biol Chem 2004, 279:7370-7377.

52. Brunn GJ, Bungum MK, Johnson GB, Platt JL: Conditional signaling by Tolllike receptor 4. FASEB J 2005, 19:872-874.

53. Mencin A, Kluwe J, Schwabe RF: Toll-like receptors as targets in chronic liver diseases. Gut 2009, 58:704-720.

54. Guo J, Loke J, Zheng F, Hong F, Yea S, Fukata M, Tarocchi M, Abar OT, Huang H, Sninsky JJ, Friedman SL: Functional linkage of cirrhosispredictive single nucleotide polymorphisms of Toll-like receptor 4 to hepatic stellate cell responses. Hepatology 2009, 49:960-968.

55. Kao YH, Jawan B, Goto S, Hung CT, Lin YC, Nakano T, Hsu LW, Lai CY, Tai MH, Chen CL: High-mobility group box 1 protein activates hepatic stellate cells in vitro. Transplant Proc 2008, 40:2704-2705.

56. Wang $\mathrm{H}$, Bloom O, Zhang M, Vishnubhakat JM, Ombrellino M, Che J, Frazier A, Yang H, Ivanova S, Borovikova L, et al: HMG-1 as a late mediator of endotoxin lethality in mice. Science 1999, 285:248-251.

57. Hunter MJCW: High level expression and dimer characterization of the S100 EF-hand proteins, migration inhibitory factor relateed proteins 8 and 14. J Biol Chem 1998, 273:12437-12435.

58. Kerkhoff CKM, Sorg C: Novel insights into structure and function of MRP8 (S100A8) and MRP14 (S100A9). Biochemica et Biophysica Acta 1998, 1448:200-211.

59. Vogl T, Tenbrock K, Ludwig S, Leukert N, Ehrhardt C, van Zoelen MA, Nacken W, Foell D, van der Poll T, Sorg C, Roth J: Mrp8 and Mrp14 are endogenous activators of Toll-like receptor 4, promoting lethal, endotoxin-induced shock. Nat Med 2007, 13:1042-1049.

60. van Zoelen MA, Vogl T, Foell D, Van Veen SQ, van Till JW, Florquin S, Tanck MW, Wittebole X, Laterre PF, Boermeester MA, et al: Expression and role of myeloid-related protein-14 in clinical and experimental sepsis. Am J Respir Crit Care Med 2009, 180:1098-1106.

61. Hodgkinson CP, Patel K, Ye S: Functional Toll-like receptor 4 mutations modulate the response to fibrinogen. Thromb Haemost 2008, 100:301-307.

62. Weatherill AR, Lee JY, Zhao L, Lemay DG, Youn HS, Hwang DH: Saturated and polyunsaturated fatty acids reciprocally modulate dendritic cell functions mediated through TLR4. J Immunol 2005, 174:5390-5397.

63. Suganami T, Mieda T, Itoh M, Shimoda Y, Kamei Y, Ogawa Y: Attenuation of obesity-induced adipose tissue inflammation in $\mathrm{C} 3 \mathrm{H} / \mathrm{HeJ}$ mice carrying a Toll-like receptor 4 mutation. Biochem Biophys Res Commun 2007, 354:45-49.

64. Suganami T, Tanimoto-Koyama K, Nishida J, Itoh M, Yuan X, Mizuarai S, Kotani H, Yamaoka S, Miyake K, Aoe S, et al: Role of the Toll-like receptor 4/NF-kappaB pathway in saturated fatty acid-induced inflammatory changes in the interaction between adipocytes and macrophages. Arterioscler Thromb Vasc Biol 2007, 27:84-91.

65. Erridge C, Samani NJ: Saturated fatty acids do not directly stimulate Tolllike receptor signaling. Arterioscler Thromb Vasc Biol 2009, 29:1944-1949.

66. Kitazawa T, Tsujimoto T, Kawaratani H, Fujimoto M, Fukui H: Expression of Toll-like receptor 4 in various organs in rats with D-galactosamineinduced acute hepatic failure. J Gastroenterol Hepatol 2008, 23:e494-498.

67. Wu J, Meng Z, Jiang M, Zhang E, Trippler M, Broering R, Bucchi A, Krux F, Dittmer $U$, Yang D, et al: Toll-like receptor-induced innate immune responses in non-parenchymal liver cells are cell type-specific. Immunology 2009, 129:363-374.

68. Scott MJ, Billiar TR: Beta2-integrin-induced p38 MAPK activation is a key mediator in the CD14/TLR4/MD2-dependent uptake of lipopolysaccharide by hepatocytes. J Biol Chem 2008, 283:29433-29446.

69. Galloway E, Shin T, Huber N, Eismann T, Kuboki S, Schuster R, Blanchard J, Wong HR, Lentsch AB: Activation of hepatocytes by extracellular heat shock protein 72. Am J Physiol Cell Physiol 2008, 295:C514-520.

70. Machida K, Tsukamoto H, Mkrtchyan H, Duan L, Dynnyk A, Liu HM, Asahina K, Govindarajan S, Ray R, Ou JH, et al: Toll-like receptor 4 mediates synergism between alcohol and $\mathrm{HCV}$ in hepatic oncogenesis involving stem cell marker Nanog. Proc Natl Acad Sci USA 2009, 106:1548-1553.

71. Schwabe RF, Seki E, Brenner DA: Toll-like receptor signaling in the liver. Gastroenterology 2006, 130:1886-1900.

72. Guo JSLJ, Zheng F, Hong F, Yea S, Fugita M, Tarocchi M, Abar OT, Huang HJ, Sninsky JJ, Friedman SL: Functional Linkage of CirrhosisPredictive Single Nucleotide Polymorphisms of Toll-like Receptor 4 to Hepatic Stellate Cell Responses. Hepatology 2009, 49:960-968. 
73. Chen LC, Gordon RE, Laskin JD, Laskin DL: Role of TLR4 in liver macrophage and endothelial cell responsiveness during acute endotoxemia. Exp Mol Pathol 2007, 83:311-326.

74. Hayashi T, Kishiwada M, Fujii K, Yuasa H, Nishioka J, Ido M, Gabazza EC, Suzuki K: Lipopolysaccharide-induced decreased protein $S$ expression in liver cells is mediated by MEK/ERK signaling and NFkappaB activation: involvement of membrane-bound CD14 and Toll like receptor-4. J Thromb Haemost 2006, 4:1763-1773.

75. Harada K, Ohira S, Isse K, Ozaki S, Zen Y, Sato Y, Nakanuma Y: Lipopolysaccharide activates nuclear factor-kappaB through Toll like receptors and related molecules in cultured biliary epithelial cells. Lab Invest 2003, 83:1657-1667.

76. Chen XM, O'Hara SP, Nelson JB, Splinter PL, Small AJ, Tietz PS, Limper AH, LaRusso NF: Multiple TLRs are expressed in human cholangiocytes and mediate host epithelial defense responses to Cryptosporidium parvum via activation of NF-kappaB. J Immunol 2005, 175:7447-7456.

77. Yokoyama T, Komori A, Nakamura M, Takii Y, Kamihira T, Shimoda S, Mori T, Fujiwara S, Koyabu M, Taniguchi K, et al: Human intrahepatic biliary epithelial cells function in innate immunity by producing IL-6 and IL-8 via the TLR4-NF-kappaB and -MAPK signaling pathways. Liver Int 2006, 26:467-476.

78. Harada K, Isse K, Sato Y, Ozaki S, Nakanuma Y: Endotoxin tolerance in human intrahepatic biliary epithelial cells is induced by upregulation of IRAK-M. Liver Int 2006, 26:935-942.

79. De Creus A, Abe M, Lau AH, Hackstein H, Raimondi G, Thomson AW: Low TLR4 expression by liver dendritic cells correlates with reduced capacity to activate allogeneic T cells in response to endotoxin. J Immunol 2005, 174:2037-2045

80. Okamoto M, Furuichi S, Nishioka Y, Oshikawa T, Tano T, Ahmed SU, Takeda K, Akira S, Ryoma Y, Moriya Y, et al: Expression of Toll like receptor 4 on dendritic cells is significant for anticancer effect of dendritic cellbased immunotherapy in combination with an active component of OK432, a streptococcal preparation. Cancer Res 2004, 64:5461-5470.

81. Matsuoka N, Itoh T, Watarai H, Sekine-Kondo E, Nagata N, Okamoto K, Mera T, Yamamoto H, Yamada S, Maruyama I, et al: High-mobility group box 1 is involved in the initial events of early loss of transplanted islets in mice. J Clin Invest 2010, 120:735-743.

82. Martin-Vilchez S, Molina-Jimenez F, Alonso-Lebrero JL, Sanz-Cameno P, Rodriguez-Munoz Y, Benedicto I, Roda-Navarro P, Trapero M, AragonesesFenoll L, Gonzalez S, et al: AM3, a natural glycoconjugate, induces the functional maturation of human dendritic cells. Br J Pharmacol 2008, 154:698-708.

83. Selmi C, Mackay IR, Gershwin ME: The immunological milieu of the liver. Semin Liver Dis 2007, 27:129-139.

84. Pasare C, Medzhitov R: Toll-like receptors: linking innate and adaptive immunity. Adv Exp Med Biol 2005, 560:11-18.

85. Dai J, Liu B, Li Z: Regulatory T cells and Toll-like receptors: what is the missing link? Int Immunopharmacol 2009, 9:528-533.

86. Caramalho I, Lopes-Carvalho T, Ostler D, Zelenay S, Haury M, Demengeot J: Regulatory $\mathrm{T}$ cells selectively express Toll like receptors and are activated by lipopolysaccharide. J Exp Med 2003, 197:403-411.

87. Papadimitraki ED, Bertsias GK, Boumpas DT: Toll like receptors and autoimmunity: a critical appraisal. J Autoimmun 2007, 29:310-318.

88. Vazquez-Torres A, Vallance BA, Bergman MA, Finlay BB, Cookson BT, JonesCarson J, Fang FC: Toll-like receptor 4 dependence of innate and adaptive immunity to Salmonella: importance of the Kupffer cell network. J Immunol 2004, 172:6202-6208.

89. Yohe HC, O'Hara KA, Hunt JA, Kitzmiller TJ, Wood SG, Bement JL, Bement WJ, Szakacs JG, Wrighton SA, Jacobs JM, et al: Involvement of Tolllike receptor 4 in acetaminophen hepatotoxicity. Am J Physiol Gastrointest Liver Physiol 2006, 290:G1269-1279.

90. Williams AM, Langley PG, Osei-Hwediah J, Wendon JA, Hughes RD: Hyaluronic acid and endothelial damage due to paracetamol-induced hepatotoxicity. Liver Int 2003, 23:110-115.

91. Bramley PN, Rathbone BJ, Forbes MA, Cooper EH, Losowsky MS: Serum hyaluronate as a marker of hepatic derangement in acute liver damage. J Hepatol 1991, 13:8-13.

92. Wu J, Lu M, Meng Z, Trippler M, Broering R, Szczeponek A, Krux F, Dittmer U, Roggendorf M, Gerken G, Schlaak JF: Toll-like receptormediated control of HBV replication by nonparenchymal liver cells in mice. Hepatology 2007, 46:1769-1778.
93. Broering R, Wu J, Meng Z, Hilgard P, Lu M, Trippler M, Szczeponek A, Gerken G, Schlaak JF: Toll-like receptor-stimulated non-parenchymal liver cells can regulate hepatitis C virus replication. J Hepatol 2008, 48:914-922.

94. Isogawa M, Robek MD, Furuichi Y, Chisari FV: Toll-like receptor signaling inhibits hepatitis B virus replication in vivo. J Virol 2005, 79:7269-7272.

95. Wang JP, Zhang Y, Wei X, Li J, Nan XP, Yu HT, Li Y, Wang PZ, Bai XF: Circulating Toll-like receptor (TLR) 2, TLR4, and regulatory T cells in patients with chronic hepatitis C. APMIS 2010, 118:261-270.

96. Zeyda M, Stulnig TM: Obesity, inflammation, and insulin resistance-a mini-review. Gerontology 2009, 55:379-386.

97. Shi H, Kokoeva MV, Inouye K, Tzameli I, Yin H, Flier JS: TLR4 links innate immunity and fatty acid-induced insulin resistance. J Clin Invest 2006, 116:3015-3025.

98. Budick-Harmelin N, Dudas J, Demuth J, Madar Z, Ramadori G, Tirosh O: Triglycerides potentiate the inflammatory response in rat Kupffer cells. Antioxid Redox Signal 2008, 10:2009-2022.

99. Spruss A, Kanuri G, Wagnerberger S, Haub S, Bischoff SC, Bergheim I: Tolllike receptor 4 is involved in the development of fructose-induced hepatic steatosis in mice. Hepatology 2009, 50:1094-1104.

100. Thuy S, Ladurner R, Volynets V, Wagner S, Strahl S, Konigsrainer A, Maier KP, Bischoff SC, Bergheim I: Nonalcoholic fatty liver disease in humans is associated with increased plasma endotoxin and plasminogen activator inhibitor 1 concentrations and with fructose intake. J Nutr 2008, 138:1452-1455

101. Mandrekar P, Szabo G: Signalling pathways in alcohol-induced liver inflammation. J Hepatol 2009, 50:1258-1266.

102. Szabo G, Bala S: Alcoholic liver disease and the gut-liver axis. World J Gastroenterol 2010, 16:1321-1329.

103. Hines IN, Wheeler MD: Recent advances in alcoholic liver disease III. Role of the innate immune response in alcoholic hepatitis. Am J Physiol Gastrointest Liver Physiol 2004, 287:G310-314.

104. Wang AP, Migita K, Ito M, Takii Y, Daikoku M, Yokoyama T, Komori A, Nakamura M, Yatsuhashi H, Ishibashi H: Hepatic expression of Toll like receptor 4 in primary biliary cirrhosis. J Autoimmun 2005, 25:85-91.

105. Karrar A, Broome U, Sodergren T, Jaksch M, Bergquist A, Bjornstedt M, Sumitran-Holgersson S: Biliary epithelial cell antibodies link adaptive and innate immune responses in primary sclerosing cholangitis. Gastroenterology 2007, 132:1504-1514.

106. Tsung A, Hoffman RA, Izuishi K, Critchlow ND, Nakao A, Chan MH, Lotze MT Geller DA, Billiar TR: Hepatic ischemia/reperfusion injury involves functional TLR4 signaling in nonparenchymal cells. J Immunol 2005, 175:7661-7668.

107. Tsung A, Zheng N, Jeyabalan G, Izuishi K, Klune JR, Geller DA, Lotze MT, Lu L, Billiar TR: Increasing numbers of hepatic dendritic cells promote HMGB1-mediated ischemia-reperfusion injury. J Leukoc Biol 2007, 81:119-128.

108. Hui W, Jinxiang Z, Heshui W, Zhuoya L, Qichang Z: Bone marrow and nonbone marrow TLR4 regulates hepatic ischemia/reperfusion injury. Biochem Biophys Res Commun 2009, 389:328-332.

109. Shen XD, Ke B, Zhai Y, Gao F, Busuttil RW, Cheng G, Kupiec-Weglinski JW: Toll-like receptor and heme oxygenase-1 signaling in hepatic ischemia/ reperfusion injury. Am J Transplant 2005, 5:1793-1800.

110. Deng JF, Geng L, Qian YG, Li H, Wang Y, Xie HY, Feng XW, Zheng SS: The role of Toll like receptors 2 and 4 in acute allograft rejection after liver transplantation. Transplant Proc 2007, 39:3222-3224.

111. Dhillon N, Walsh L, Kruger B, Ward SC, Godbold JH, Radwan M, Schiano T, Murphy BT, Schroppel B: A single nucleotide polymorphism of Toll-like receptor 4 identifies the risk of developing graft failure after liver transplantation. J Hepatol 53:67-72.

112. Bosma BM, Metselaar HJ, Gerrits JH, van Besouw NM, Mancham S, Groothuismink ZM, Boor PP, van der Laan LJ, Tilanus HW, Kuipers EJ, Kwekkeboom J: Migration of allosensitizing donor myeloid dendritic cells into recipients after liver transplantation. Liver Transp/ 16:12-22.

113. Tazi KA, Quioc JJ, Saada V, Bezeaud A, Lebrec D, Moreau R: Upregulation of TNF-alpha production signaling pathways in monocytes from patients with advanced cirrhosis: possible role of Akt and IRAK-M. J Hepatol 2006, 45:280-289.

114. Friedman SL: Seminars in medicine of the Beth Israel Hospital, Boston. The cellular basis of hepatic fibrosis. Mechanisms and treatment strategies. N Engl J Med 1993, 328:1828-1835.

115. Friedman SL: Hepatic fibrosis - overview. Toxicology 2008, 254:120-129. 
116. Guo J, Friedman SL: Hepatic fibrogenesis. Semin Liver Dis 2007, 27:413-426.

117. Holt AP, Salmon M, Buckley CD, Adams DH: Immune interactions in hepatic fibrosis. Clin Liver Dis 2008, 12:861-882.

118. Brun P, Castagliuolo I, Pinzani M, Palu G, Martines D: Exposure to bacterial cell wall products triggers an inflammatory phenotype in hepatic stellate cells. Am J Physiol Gastrointest Liver Physiol 2005, 289:G571-578.

119. Marra F, Romanelli RG, Giannini C, Failli P, Pastacaldi S, Arrighi MC, Pinzani M, Laffi G, Montalto P, Gentilini P: Monocyte chemotactic protein-1 as a chemoattractant for human hepatic stellate cells. Hepatology 1999, 29:140-148.

120. Marra F, DeFranco R, Grappone C, Parola M, Milani S, Leonarduzzi G, Pastacaldi S, Wenzel UO, Pinzani M, Dianzani MU, et al: Expression of monocyte chemotactic protein-1 precedes monocyte recruitment in a rat model of acute liver injury, and is modulated by vitamin E. J Investig Med 1999, 47:66-75.

121. Huang H, Shiffman ML, Friedman S, Venkatesh R, Bzowej N, Abar OT, Rowland CM, Catanese JJ, Leong DU, Sninsky JJ, et al: A 7 gene signature identifies the risk of developing cirrhosis in patients with chronic hepatitis C. Hepatology 2007, 46:297-306.

122. Isayama F, Hines IN, Kremer M, Milton RJ, Byrd CL, Perry AW, McKim SE, Parsons C, Rippe RA, Wheeler MD: LPS signaling enhances hepatic fibrogenesis caused by experimental cholestasis in mice. Am J Physiol Gastrointest Liver Physiol 2006, 290:G1318-1328.

123. Rallabhandi P, Bell J, Boukhvalova MS, Medvedev A, Lorenz E, Arditi M, Hemming VG, Blanco JC, Segal DM, Vogel SN: Analysis of TLR4 polymorphic variants: new insights into TLR4/MD2/CD14 stoichiometry, structure, and signaling. J Immunol 2006, 177:322-332

124. White SN, Taylor KH, Abbey CA, Gill CA, Womack JE: Haplotype variation in bovine Toll-like receptor 4 and computational prediction of a positively selected ligand-binding domain. Proc Natl Acad Sci USA 2003, 100:10364-10369.

125. Smirnova I, Hamblin MT, McBride C, Beutler B, Di Rienzo A: Excess of rare amino acid polymorphisms in the Toll-like receptor 4 in humans. Genetics 2001, 158:1657-1664.

126. Arbour NC, Lorenz E, Schutte BC, Zabner J, Kline JN, Jones M, Frees K, Watt JL, Schwartz DA: TLR4 mutations are associated with endotoxin hyporesponsiveness in humans. Nat Genet 2000, 25:187-191.

127. Okayama N, Fujimura K, Suehiro Y, Hamanaka Y, Fujiwara M, Matsubara T, Maekawa T, Hazama S, Oka M, Nohara H, et al: Simple genotype analysis of the Asp299Gly polymorphism of the Toll-like receptor-4 gene that is associated with lipopolysaccharide hyporesponsiveness. J Clin Lab Anal 2002, 16:56-58.

128. Agnese DM, Calvano JE, Hahm SJ, Coyle SM, Corbett SA, Calvano SE, Lowry SF: Human Toll like receptor 4 mutations but not CD14 polymorphisms are associated with an increased risk of gram-negative infections. J Infect Dis 2002, 186:1522-1525.

129. Mockenhaupt FP, Cramer JP, Hamann L, Stegemann MS, Eckert J, Oh NR, Otchwemah RN, Dietz E, Ehrhardt S, Schroder NW, et al: Toll-like receptor (TLR) polymorphisms in African children: Common TLR-4 variants predispose to severe malaria. Proc Natl Acad Sci USA 2006, 103:177-182.

130. Browning BL, Huebner C, Petermann I, Gearry RB, Barclay ML, Shelling AN, Ferguson LR: Has Toll like receptor 4 been prematurely dismissed as an inflammatory bowel disease gene? Association study combined with meta-analysis shows strong evidence for association. Am J Gastroenterol 2007, 102:2504-2512.

131. Tulic MK, Hurrelbrink RJ, Prele CM, Laing IA, Upham JW, Le Souef P, Sly PD, Holt PG: TLR4 polymorphisms mediate impaired responses to respiratory syncytial virus and lipopolysaccharide. J Immunol 2007, 179:132-140.

132. Schroder NW, Schumann RR: Single nucleotide polymorphisms of Toll-like receptors and susceptibility to infectious disease. Lancet Infect Dis 2005, 5:156-164.

133. van Rijn BB, Franx A, Steegers EA, de Groot CJ, Bertina RM, Pasterkamp G, Voorbij HA, Bruinse HW, Roest M: Maternal TLR4 and NOD2 gene variants, pro-inflammatory phenotype and susceptibility to early-onset preeclampsia and HELLP syndrome. PLoS One 2008, 3:e1865.

134. Hold GL, Rabkin CS, Chow WH, Smith MG, Gammon MD, Risch HA, Vaughan TL, McColl KE, Lissowska J, Zatonski W, et al: A functional polymorphism of Toll like receptor 4 gene increases risk of gastric carcinoma and its precursors. Gastroenterology 2007, 132:905-912.

135. Kilding R, Akil M, Till S, Amos R, Winfield J, lles MM, Wilson AG: A biologically important single nucleotide polymorphism within the Toll like receptor-4 gene is not associated with rheumatoid arthritis. Clin Exp Rheumatol 2003, 21:340-342.

136. Zheng B, Li Q, Wei C, Qin J, Shou T, Zhou R, Shao J, Yang Y, Xiao C: Lack of association of TLR4 gene Asp299Gly and Thr399lle polymorphisms with rheumatoid arthritis in Chinese Han population of Yunnan Province. Rheumatol Int 2010, 30:1249-1252.

137. Sheedy FJ, Marinou I, O'Neill LA, Wilson AG: The Mal/TIRAP S180L and TLR4 G299D polymorphisms are not associated with susceptibility to, or severity of, rheumatoid arthritis. Ann Rheum Dis 2008, 67:1328-1331.

138. Sanchez E, Orozco G, Lopez-Nevot MA, Jimenez-Alonso J, Martin J: Polymorphisms of Toll like receptor 2 and 4 genes in rheumatoid arthritis and systemic lupus erythematosus. Tissue Antigens 2004, 63:54-57.

139. Kroner A, Vogel F, Kolb-Maurer A, Kruse N, Toyka KV, Hemmer B, Rieckmann P, Maurer M: Impact of the Asp299Gly polymorphism in the Toll like receptor 4 (TLR4) gene on disease course of multiple sclerosis. J Neuroimmunol 2005, 165:161-165.

140. Reindl M, Lutterotti A, Ingram J, Schanda K, Gassner C, Deisenhammer F, Berger T, Lorenz E: Mutations in the gene for Toll like receptor 4 and multiple sclerosis. Tissue Antigens 2003, 61:85-88

141. Gergely P Jr, Blazsek A, Weiszhar Z, Pazar B, Poor G: Lack of genetic association of the Toll-like receptor 4 (TLR4) Asp299Gly and Thr399lle polymorphisms with spondylarthropathies in a Hungarian population. Rheumatology (Oxford) 2006, 45:1194-1196.

142. Reismann P, Lichy C, Rudofsky G, Humpert PM, Genius J, Si TD, Dorfer C, Grau AJ, Hamann A, Hacke W, et al: Lack of association between polymorphisms of the Toll like receptor 4 gene and cerebral ischemia. J Neurol 2004, 251:853-858.

143. Lamb R, Zeggini E, Thomson W, Donn R: Toll-like receptor 4 gene polymorphisms and susceptibility to juvenile idiopathic arthritis. Ann Rheum Dis 2005, 64:767-769.

144. Rittersma SZ, Kremer Hovinga JA, Koch KT, Boekholdt SM, van Aken BE, Scheepmaker A, Bax M, Schotborgh CE, Piek JJ, Tijssen JG, et al: Relationship between in vitro lipopolysaccharide-induced cytokine response in whole blood, angiographic in-stent restenosis, and Toll like receptor 4 gene polymorphisms. Clin Chem 2005, 51:516-521.

145. Kruger B, Krick S, Dhillon N, Lerner SM, Ames S, Bromberg JS, Lin M, Walsh L, Vella J, Fischereder M, et al: Donor Toll-like receptor 4 contributes to ischemia and reperfusion injury following human kidney transplantation. Proc Natl Acad Sci USA 2009, 106:3390-3395.

146. Li Y, Chang M, Abar O, Garcia V, Rowland C, Catanese J, Ross D, Broder S, Shiffman M, Cheung $R$, et al: Multiple variants in Toll like receptor 4 gene modulate risk of liver fibrosis in Caucasians with chronic hepatitis $C$ infection. J Hepatol 2009, 51:750-757.

147. Beutler B: Inferences, questions and possibilities in Toll-like receptor signalling. Nature 2004, 430:257-263.

148. Tsung A, McCoy SL, Klune JR, Geller DA, Billiar TR, Hefeneider SH: A novel inhibitory peptide of Toll-like receptor signaling limits lipopolysaccharide-induced production of inflammatory mediators and enhances survival in mice. Shock 2007, 27:364-369.

149. Visintin A, Halmen KA, Latz E, Monks BG, Golenbock DT: Pharmacological inhibition of endotoxin responses is achieved by targeting the TLR4 coreceptor, MD2. J Immunol 2005, 175:6465-6472.

150. Kitazawa T, Tsujimoto T, Kawaratani H, Fukui H: Therapeutic approach to regulate innate immune response by Toll-like receptor 4 antagonist E5564 in rats with D-galactosamine-induced acute severe liver injury. $J$ Gastroenterol Hepatol 2009, 24:1089-1094.

151. Fort MM, Mozaffarian A, Stover AG, Correia Jda S, Johnson DA, Crane RT, Ulevitch RJ, Persing DH, Bielefeldt-Ohmann H, Probst P, et al: A synthetic TLR4 antagonist has anti-inflammatory effects in two murine models of inflammatory bowel disease. J Immunol 2005, 174:6416-6423.

152. Takashima K, Matsunaga N, Yoshimatsu M, Hazeki K, Kaisho T, Uekata M, Hazeki O, Akira S, lizawa Y, li M: Analysis of binding site for the novel smallmolecule TLR4 signal transduction inhibitor TAK-242 and its therapeutic effect on mouse sepsis model. Br J Pharmacol 2009, 157:1250-1262.

153. Schnabl B, Brandl K, Fink M, Gross P, Taura K, Gabele E, Hellerbrand C, Falk W: A TLR4/MD2 fusion protein inhibits LPS-induced proinflammatory signaling in hepatic stellate cells. Biochem Biophys Res Commun 2008, 375:210-214.

154. Chen LC, Laskin JD, Gordon MK, Laskin DL: Regulation of TREM expression in hepatic macrophages and endothelial cells during acute endotoxemia. Exp Mol Pathol 2008, 84:145-155. 
155. Lembo A, Pelletier M, lyer R, Timko M, Dudda JC, West TE, Wilson CB, Hajjar AM, Skerrett SJ: Administration of a synthetic TLR4 agonist protects mice from pneumonic tularemia. J Immunol 2008, 180:7574-7581.

156. McHutchison JG, Bacon BR, Gordon SC, Lawitz E, Shiffman M, Afdhal NH, Jacobson IM, Muir A, Al-Adhami M, Morris ML, et al: Phase 1B, randomized, double-blind, dose-escalation trial of CPG 10101 in patients with chronic hepatitis C virus. Hepatology 2007, 46:1341-1349.

doi:10.1186/1755-1536-3-21

Cite this article as: Guo and Friedman: Toll-like receptor 4 signaling in liver injury and hepatic fibrogenesis. Fibrogenesis \& Tissue Repair 2010 3:21

Submit your next manuscript to BioMed Central and take full advantage of:

- Convenient online submission

- Thorough peer review

- No space constraints or color figure charges

- Immediate publication on acceptance

- Inclusion in PubMed, CAS, Scopus and Google Scholar

- Research which is freely available for redistribution

Submit your manuscript at www.biomedcentral.com/submit 